\title{
Reconciling opposing views on carbon cycling in the coastal ocean: Continental shelves as sinks and near-shore ecosystems as sources of atmospheric $\mathrm{CO}_{2}$
}

\author{
Chen-Tung Arthur Chen ${ }^{\mathrm{a}, *}$, Alberto V. Borges ${ }^{\mathrm{b}}$ \\ a Institute of Marine Geology and Chemistry, National Sun Yat-sen University, Kaohsiung 804, Taiwan, Republic of China \\ b Chemical Oceanography Unit, MARE University of Liège Allée du 6 Août, 17 (Bât B5), B-4000 Liège, Belgium
}

\section{A R T I C L E I N F O}

Available online 16 January 2009

Keywords:

Coastal ocean

Continental shelves

Estuaries

$\mathrm{CO}_{2}$

Carbon cycle

\begin{abstract}
A B S T R A C T
Despite their moderately sized surface area, continental marginal seas play a significant role in the biogeochemical cycles of carbon, as they receive huge amounts of upwelled and riverine inputs of carbon and nutrients, sustaining a disproportionate large biological activity compared to their relative surface area. A synthesis of worldwide measurements of the partial pressure of $\mathrm{CO}_{2}\left(\mathrm{pCO}_{2}\right)$ indicates that most open shelves in the temperate and high-latitude regions are under-saturated with respect to atmospheric $\mathrm{CO}_{2}$ during all seasons, although the low-latitude shelves seem to be over-saturated. Most inner estuaries and near-shore coastal areas on the other hand are over-saturated with respect to atmospheric $\mathrm{CO}_{2}$. The scaling of air-sea $\mathrm{CO}_{2}$ fluxes based on $\mathrm{pCO}_{2}$ measurements and carbon massbalance calculations indicate that the continental shelves absorb atmospheric $\mathrm{CO}_{2}$ ranging between 0.33 and $0.36 \mathrm{Pg} \mathrm{Cyr}^{-1}$ that corresponds to an additional sink of $27 \%$ to $\sim 30 \%$ of the $\mathrm{CO}_{2}$ uptake by the open oceans based on the most recent $\mathrm{pCO}_{2}$ climatology [Takahashi, T., Sutherland, S.C., Wanninkhof, R., Sweeney, C., Feely, R.A., Chipman, D., Hales, B., Friederich, G., Chavez, F., Watson, A., Bakker, D., Schuster, U., Metzl, N., Inoue, H.Y., Ishii, M., Midorikawa, T., Sabine, C., Hoppema, M., Olafsson, J., Amarson, T., Tilbrook, B., Johannessen, T., Olsen, A., Bellerby, R., De Baar, H., Nojiri, Y., Wong, C.S., Delille, B., Bates, N., 2009. Climatological mean and decadal change in surface ocean $\mathrm{pCO}_{2}$, and net sea-air $\mathrm{CO}_{2}$ flux over the global oceans. Deep-Sea Research II, this issue [doi: 10.1016/j.dsr2.2008.12.009].]. Inner estuaries, salt

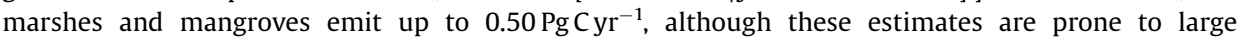
uncertainty due to poorly constrained ecosystem surface area estimates. Nevertheless, the view of continental shelves as sinks and near-shore ecosystems as sources of atmospheric $\mathrm{CO}_{2}$ allows reconciling long-lived opposing views on carbon cycling in the coastal ocean.
\end{abstract}

(c) 2009 Elsevier Ltd. All rights reserved.

\section{Background}

Land, rivers, open ocean, atmosphere, sediments and biota interact in coastal and shelf seas, leading to substantial spatial and temporal heterogeneity in carbon flows. Although the continental margins, considered here to extend from the coastline to a depth of $200 \mathrm{~m}$, occupy only a little over $7 \%$ of the seafloor and less than $0.5 \%$ of the ocean volume, they play a major role in oceanic biogeochemical cycling. Significantly higher rates of new primary production occur in the continental margins than in the open oceans because of the higher supply of nutrients from cross-shelf break upwelling and riverine input, in addition to the rapid remineralization of organic matter due to enhanced pelagic and

\footnotetext{
* Corresponding author. Tel.: +8867525 5146; fax: +88675255346

E-mail addresses: ctchen@mail.nsysu.edu.tw (C.-T.A. Chen), alberto.borges@ulg.ac.be (A.V. Borges).
}

benthic coupling (Walsh, 1988, 1991; Mackenzie et al., 1998a, b; Wollast, 1998; Liu et al., 2000; Muller-Karger et al., 2005).

Recognizing the importance of the continental margins in terms of the cycling of carbon and associated elements, the Joint Global Ocean Flux Study (JGOFS, established in 1988 as a core project under the International Geosphere Biosphere Program, IGBP) adopted continental margin studies as one of its operational elements. Five years later, another IGBP core project, the LandOcean Interaction in the Coastal Zone (LOICZ), was established to study in detail carbon and nutrient flows in coastal ecosystems. The first of four over-arching objectives of LOICZ was to determine the fluxes of materials between land, sea and atmosphere.

The first two of the six LOICZ foci were: Is the coastal zone a sink or source of $\mathrm{CO}_{2}$ and What are mass balances of carbon, nitrogen and phosphorus in the coastal zone? (Crossland et al., 2005). The very first LOICZ report was entitled "Coastal seas: a net source or sink of atmosphere carbon dioxide?" (Kempe, 1995). These questions arise because it is not clear how much of the 
organic carbon transported to the coastal seas by rivers and new production on the continental shelves is permanently sequestered by export to the deep oceans or to sediments on the shelves and shallow marginal seas.

In order to determine the contribution of continental margins and seas to $\mathrm{CO}_{2}$ sequestration and the horizontal fluxes of carbon, nitrogen and phosphorus across the ocean-continental margin boundary, the JGOFS/LOICZ Continental Margins Task Team (CMTT) was established (Chen et al., 1994).

Unfortunately, even now there is still a great deal of discussion about very basic questions on whether coastal waters are net sources or sinks of atmospheric $\mathrm{CO}_{2}$, and whether primary production in coastal seas is exported or recycled. For instance, Smith and Mackenzie (1987) and Smith and Hollibaugh (1993) claimed that the oceans as a whole are net heterotrophic, and that they release more $\mathrm{CO}_{2}$ into the atmosphere than they take up. Their argument was based on the imbalance between the total river transport of about $0.40 \mathrm{PgC} \mathrm{yr}^{-1}$ and the oceanic organic carbon burial rate of around $0.14 \mathrm{PgCyr}^{-1}$. The difference of $0.26 \mathrm{PgC}^{-1}$ would be most likely returned to the atmosphere. Ver et al. (1999a, b) and Mackenzie et al. (2000) also concluded that, in spite of an increased invasion of $\mathrm{CO}_{2}$ from the atmosphere to the continental margins driven by the rise in atmospheric $\mathrm{CO}_{2}$, continental margin waters are heterotrophic or, simply restated, sources of $\mathrm{CO}_{2}$ to the atmosphere.

Upon the conclusion of the JGOFS project, Fasham et al. (2001) adopted the same view and reported a net $\mathrm{CO}_{2}$ sea-to-air flux of $0.5 \mathrm{PgC} \mathrm{yr}^{-1}$ for continental margins. Noteworthy is that these authors, nevertheless, literally inserted a question mark alongside this value, which is larger than not only the value of $0.1 \mathrm{PgC} \mathrm{yr}^{-1}$ reported by Ver et al. (1999a,b) but also than the total river transport of $0.4 \mathrm{PgCyr}^{-1}$ cited by Smith and Mackenzie (1987) and Smith and Hollibaugh (1993). As for LOICZ, the synthesis of first decade's activities ending in 2002 did not seem to answer properly the question as to whether the coastal zones are sources or sinks of carbon (Crossland et al., 2005). The chapter on "C, N, P fluxes in the coastal zone" did not provide any data on the atmosphere-marginal sea or on the shelf-open ocean fluxes of carbon but nevertheless concluded that "Smith and Hollibaugh (1993) estimated that there is about $7 \times 10^{12} \mathrm{molyr}^{-1}$ of net carbon oxidation in the coastal zone and $16 \times 10^{12} \mathrm{~mol} \mathrm{yr}^{-1}$ in the open ocean. The LOICZ analysis does nothing to alter this essential picture". And, the "Preface" of the synthesis volume simply states that "The question of whether the coastal zone is a source or sink of carbon is examined".

Despite some uncertainties (Borges, 2005; Borges et al., 2005; Cai et al., 2006), mounting evidence based on $\mathrm{pCO}_{2}$ measurements and mass-balance calculations (Chen et al., 2003; Chen, 2004) seems to indicate that the continental shelves are actually sinks of atmospheric $\mathrm{CO}_{2}$. A chapter in the JGOFS synthesis volume concluded that the shelves take up $25 \times 10^{12} \mathrm{molyr}^{-1}$ of atmospheric $\mathrm{CO}_{2}$ based mainly on the mass-balance approach (Chen et al., 2003). A chapter in the assessment organized by the Global Carbon Project gave an air-to-sea $\mathrm{CO}_{2}$ flux of $30 \times 10^{12} \mathrm{~mol} \mathrm{yr}^{-1}$ for the shelves (Chen, 2004). These fluxes, however, do not include inner estuaries, salt marshes or mangroves, which release $\mathrm{CO}_{2}$ to the atmosphere (Borges, 2005; Borges et al., 2005). This emission of $\mathrm{CO}_{2}$ is fuelled by inputs of terrestrial organic matter.

There is increasing evidence that a very large fraction of terrestrial/riverine organic matter is degraded and emitted as $\mathrm{CO}_{2}$ to the atmosphere in these near-shore systems, and never reaches the continental shelves let alone the open ocean (e.g. Middelburg and Herman, 2007, and references therein). Hence, the "coastal" net heterotrophy postulated by Smith and Mackenzie (1987) and Smith and Hollibaugh (1993) is confined to these near-shore ecosystems, which allows one to reconcile their mass-balance approach with the wealth of evidence showing that marginal seas are net autotrophic and net sinks for atmospheric $\mathrm{CO}_{2}$.

It will be shown below that the available data of $\mathrm{pCO}_{2}$ measurements in about 60 continental shelves of the world allows the conclusion that continental shelves are indeed sinks for atmospheric carbon. The present work updates previous compilations of $\mathrm{pCO}_{2}$ measurements in coastal environments (Borges, 2005; Borges et al., 2005; Cai et al., 2006) and attempts to reconcile long-lived opposing views on $\mathrm{C}$ cycling in marginal seas, either as net heterotrophic and potential sources of $\mathrm{CO}_{2}$ to the atmosphere (e.g. Smith and Mackenzie, 1987; Smith and Hollibaugh, 1993) or as autotrophic and potential sinks for atmospheric $\mathrm{CO}_{2}$ (e.g. Gattuso et al., 1998; Wollast, 1998; Chen, 2004).

\section{Air-sea $\mathrm{CO}_{2}$ fluxes in inner estuaries, salt marshes and mangroves}

Table 1 compiles available air-water $\mathrm{CO}_{2}$ fluxes in near-shore ecosystems (inner estuaries, salt marshes and mangrove surrounding waters) and updates previous global compilations by Abril and Borges (2004), Borges (2005) and Borges et al. (2005), with an increase of almost $50 \%$ in available data. Notable differences with previous compilations are that data for some major inner estuaries are now available such as the Changjiang (ranked 4th river in the world in terms of freshwater discharge, Gao et al., 2005; Zhai et al., 2007) and the Mekong (ranked 10th river in the world in terms of freshwater discharge, Borges, unpublished), and for previously undocumented lagoons (four systems in The Ivory Coast (Koné et al., 2009) and Aveiro lagoon (Borges and Frankignoulle unpublished)). Also, information on the seasonality of $\mathrm{CO}_{2}$ fluxes in mangrove surrounding waters is now available (Koné and Borges, 2008) and $\mathrm{CO}_{2}$ fluxes in salt marshes are available at an additional site.

Inner estuaries act as sources of $\mathrm{CO}_{2}$ to the atmosphere due to their heterotrophic ecosystem metabolic status (Odum and Hoskin, 1958; Odum and Wilson, 1962; Heip et al., 1995; Kemp et al., 1997; Gattuso et al., 1998; Gazeau et al., 2004; Hopkinson and Smith, 2005). The input of dissolved $\mathrm{CO}_{2}$ from the upstream river contributes to about $10 \%$ of the emission of $\mathrm{CO}_{2}$ from macrotidal inner estuaries, the remaining fraction of the emission of $\mathrm{CO}_{2}$ is then due to heterotrophy or lateral inputs of $\mathrm{CO}_{2}$ (Borges et al., 2006). The net heterotrophy of inner estuaries is sustained by terrestrial/riverine organic carbon inputs (freshwater phytoplankton and soil carbon), and in populated areas by waste water.

Mangroves surrounding waters act as $\mathrm{CO}_{2}$ sources to the atmosphere also due to the heterotrophic nature of the water column and inter-tidal sediments. Heterotrophy is sustained by inputs of organic carbon that has several sources, either autochtonous (mangrove detritus and microphytobenthos) or allochtonous (phytoplankton, seagrass-derived material and terrestrial non-mangrove forests), and the relative contribution of these sources varies considerably from one site to another (Bouillon and Boschker, 2006). The emission of $\mathrm{CO}_{2}$ from mangrove surrounding waters is also sustained by the input of $\mathrm{CO}_{2}$-rich pore waters during ebbing (Ovalle et al., 1990; Borges et al., 2003; Bouillon et al., 2007c). Tidal pumping of pore water makes creeks waters act as conduits for the emission of $\mathrm{CO}_{2}$ produced by diagenetic organic carbon degradation, leading to an under-estimate of traditional measurements of benthic metabolism (Bouillon et al., 2007c, 2008). The aquatic compartment of salt marshes is also a source of $\mathrm{CO}_{2}$ to atmosphere due to its net heterotrophic status sustained by allochtonous and autochtonous organic carbon inputs (Cai et al., 2003; Wang and Cai, 2004), with a strong contribution of dissolved inorganic carbon (DIC) inputs 
Table 1

Longitude, latitude, $\mathrm{pCO}_{2}$ range (ppm), air-water $\mathrm{CO}_{2}$ fluxes $\left(\mathrm{FCO}_{2}\right.$ in $\left.\mathrm{mol} \mathrm{C} \mathrm{m}^{-2} \mathrm{yr}^{-1}\right)$ in near-shore ecosystems.

\begin{tabular}{|c|c|c|c|c|c|}
\hline Site (country code) & ${ }^{\circ} \mathrm{E}$ & ${ }^{\circ} \mathrm{N}$ & $\mathrm{pCO}_{2}$ range & $\mathrm{FCO}_{2}$ & References \\
\hline \multicolumn{6}{|l|}{ Inner estuaries } \\
\hline Aby lagoon (CI) & -3.3 & 4.4 & $60-325$ & 3.9 & Koné et al. (2009) \\
\hline Altamaha Sound (US) & -81.3 & 31.3 & $390-3380$ & -32.4 & Jiang et al. (2008a) \\
\hline Aveiro lagoon (PT) & -8.7 & 40.7 & $143-11,335$ & -12.4 & Borges and Frankignoulle (unpublished) \\
\hline Betsiboka (MG) & 46.3 & -15.7 & $270-1530$ & -3.3 & Ralison et al. (2008) \\
\hline Bothnian Bay (FI) & 21.0 & 63.0 & $150-550$ & -3.1 & Algesten et al. (2004) \\
\hline Changjiang (Yantze) (CN) & 120.5 & 31.5 & $200-4600$ & -24.9 & Gao et al. (2005), Zhai et al. (2007) \\
\hline Chilka (IN) & 85.5 & 19.1 & $70-6350$ & -25.0 & Gupta et al. (2008) \\
\hline Doboy Sound (US) & -81.3 & 31.4 & $390-2400$ & -13.9 & Jiang et al. (2008a) \\
\hline Douro (PT) & -8.7 & 41.1 & $1330-2200$ & -76.0 & Frankignoulle et al. (1998) \\
\hline Ebrié lagoon (CI) & -4.3 & 4.5 & $1365-3575$ & -31.1 & Koné et al. (2009) \\
\hline Elbe (DE) & 8.8 & 53.9 & $580-1100$ & -53.0 & Frankignoulle et al. (1998) \\
\hline Ems (DE) & 6.9 & 53.4 & $560-3755$ & -67.3 & Frankignoulle et al. (1998) \\
\hline Gironde (FR) & -1.1 & 45.6 & $465-2860$ & -30.8 & Frankignoulle et al. (1998) \\
\hline Godavari (IN) & 82.3 & 16.7 & $220-500$ & -5.5 & Bouillon et al. (2003) \\
\hline Guadalquivir (ES) & -6.0 & 37.4 & $520-3606$ & -31.1 & de la Paz et al. (2007) \\
\hline Hooghly (IN) & 88.0 & 22.0 & $80-1520$ & -5.1 & Mukhopadhyay et al. (2002) \\
\hline Loire (FR) & -2.2 & 47.2 & $630-2910$ & -64.4 & Abril et al. (2003) \\
\hline Mandovi-Zuari (IN) & 73.5 & 15.3 & $500-3500$ & -14.2 & Sarma et al. (2001) \\
\hline Mekong (VN) & 106.5 & 10.0 & $280-4105$ & -30.8 & Borges (unpublished) \\
\hline Potou lagoon (CI) & -3.8 & 4.6 & $1235-5120$ & -40.9 & Koné et al. (2009) \\
\hline Randers Fjord (DK) & 10.3 & 56.6 & $220-3440$ & -2.2 & Gazeau et al. (2005) \\
\hline Rhine (NL) & 4.1 & 52.0 & $545-1990$ & -39.7 & Frankignoulle et al. (1998) \\
\hline Sado (PT) & -8.9 & 38.5 & $575-5700$ & -31.3 & Frankignoulle et al. (1998) \\
\hline Sapelo Sound (US) & -81.3 & 31.6 & $390-2400$ & -13.5 & Jiang et al. (2008a) \\
\hline Saja-Besaya (ES) & -2.7 & 43.4 & $264-9728$ & -52.2 & Ortega et al. (2005) \\
\hline Satilla River (US) & -81.5 & 31.0 & $360-8200$ & -42.5 & Cai and Wang (1998) \\
\hline Scheldt (BE/NL) & 3.5 & 51.4 & $125-9425$ & -63.0 & Frankignoulle et al. (1998) \\
\hline Tagba lagoon (CI) & -5.0 & 4.4 & $800-4250$ & -18.4 & Koné et al. (2009) \\
\hline Tamar (UK) & -4.2 & 50.4 & $380-2200$ & -74.8 & Frankignoulle et al. (1998) \\
\hline Tendo lagoon (CI) & -3.2 & 4.3 & $90-3600$ & -5.1 & Koné et al. (2009) \\
\hline Thames (UK) & 0.9 & 51.5 & $505-5200$ & -73.6 & Frankignoulle et al. (1998) \\
\hline York River (US) & -76.4 & 37.2 & $350-1900$ & -6.2 & Raymond et al. (2000) \\
\hline \multicolumn{6}{|l|}{ Non-estuarine marshes } \\
\hline Duplin River (US) & -81.3 & 31.5 & $500-3000$ & -21.4 & Wang and Cai (2004) \\
\hline Rio San Pedro (ES) & -5.7 & 36.6 & $380-3760$ & -39.4 & Ferrón et al. (2007) \\
\hline \multicolumn{6}{|l|}{ Mangroves } \\
\hline Gaderu creek (IN) & 82.3 & 16.8 & $1380-4770$ & -20.4 & Borges et al. (2003) \\
\hline Kidogoweni creek (KE) & 39.5 & -4.4 & $1480-6435$ & -23.7 & Bouillon et al. (2007a) \\
\hline Itacuraça creek (BR) & -44.0 & -23.0 & $660-7700$ & -41.4 & Ovalle et al. (1990), Borges et al. (2003) \\
\hline Kiên Vàng creeks (dry season) (VN) & 105.1 & 8.7 & $705-4605$ & -11.8 & Koné and Borges (2008) \\
\hline Kiên Vàng (wet season) (VN) & 105.1 & 8.7 & $1435-8140$ & -56.5 & Koné and Borges (2008) \\
\hline Matolo/Ndogwe/Kalota/Mto Tana creeks (KE) & 40.1 & -2.1 & $490-10,035$ & -25.8 & Bouillon et al. (2007b) \\
\hline Mooringanga creek (VN) & 89.0 & 22.0 & $800-1530$ & -8.5 & Ghosh et al. (1987), Borges et al. (2003) \\
\hline Nagada creek (IN) & 145.8 & -5.2 & $540-1680$ & -15.9 & Borges et al. (2003) \\
\hline Norman's Pond (BS) & -76.1 & 23.8 & $385-750$ & -5.0 & Borges et al. (2003) \\
\hline Ras Dege creek (TZ) & 39.5 & -6.9 & $430-5050$ & -12.4 & Bouillon et al. (2007c) \\
\hline Saptamukhi creek (IN) & 89.0 & 22.0 & $1080-4000$ & -20.7 & Ghosh et al. (1987), Borges et al. (2003) \\
\hline Shark River (US) & -81.1 & 25.2 & $920-2910$ & -18.4 & Millero et al. (2001), Clark et al. (2004), Koné and Borges (2008) \\
\hline Tam Giang creeks (dry season) (IN) & 105.2 & 8.8 & $770-11,480$ & -51.6 & Koné and Borges (2008) \\
\hline Tam Giang creeks (wet season) (IN) & 105.2 & 8.8 & $1210-7150$ & -46.9 & Koné and Borges (2008) \\
\hline Tana (KE) & 40.1 & -2.1 & $2240-5305$ & -47.9 & Bouillon et al. (2007b) \\
\hline
\end{tabular}

Negative $\mathrm{FCO}_{2}$ values indicate an emission of $\mathrm{CO}_{2}$ from the water to the atmosphere.

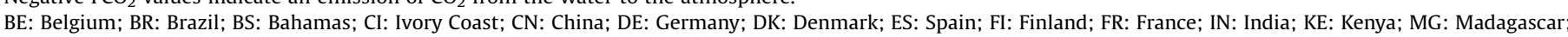
NL: The Netherlands; PT: Portugal; TZ: Tanzania; UK: United Kingdom; US: United States; VN: Vietnam.

from the inter-tidal and sub-tidal benthic compartments (Neubauer and Anderson, 2003; Ferrón et al., 2007).

It should be noted that mangrove and salt marsh ecosystems as a whole (including the aquatic compartment, the benthic compartment and above-ground biomass) act as sinks for atmospheric $\mathrm{CO}_{2}$ due to the important above-ground primary production. A recent data compilation in mangrove ecosystems yields an above-ground net primary production (including litter fall, wood production and fine root production) of $114 \mathrm{~mol} \mathrm{C} \mathrm{m}^{-2} \mathrm{yr}^{-1}$ (Bouillon et al., 2008), a sink for atmospheric $\mathrm{CO}_{2}$ that is higher than the emission of $\mathrm{CO}_{2}$ to the atmosphere from the aquatic compartment of $-27.1 \mathrm{~mol} \mathrm{C} \mathrm{m}^{-2} \mathrm{yr}^{-1}$. Similarly, in the Duplin River salt marsh ecosystem, net primary production from aboveground vegetation is about $149.2 \mathrm{~mol} \mathrm{C} \mathrm{m}^{-2} \mathrm{yr}^{-1}$ (Hopkinson, 1988), a sink of atmospheric $\mathrm{CO}_{2}$ higher than the reported emission of $\mathrm{CO}_{2}$ to the atmosphere from the aquatic compartment of $-21.4 \mathrm{~mol} \mathrm{C} \mathrm{m}{ }^{-2} \mathrm{yr}^{-1}$ (Wang and Cai, 2004). However, we only envisage in the present paper the coastal ocean $\mathrm{CO}_{2}$ fluxes, hence we only consider the $\mathrm{CO}_{2}$ exchange between the atmosphere and the aquatic compartment. 
Based on Table 1, average $\mathrm{CO}_{2}$ emissions to the atmosphere are 32.1, 30.4 and $27.1 \mathrm{~mol} \mathrm{C} \mathrm{m}^{-2} \mathrm{yr}^{-1}$ for inner estuaries, salt marsh waters and mangrove waters, respectively. Scaling of these average values yields $\mathrm{CO}_{2}$ emissions of $0.36,0.09$ and $0.05 \mathrm{PgC}$ $\mathrm{yr}^{-1}$ for inner estuaries, salt marsh waters and mangrove waters, respectively, using the Woodwell et al. (1973) estimate of surface area of inner estuarine surface area $\left(0.943 \times 10^{6} \mathrm{~km}^{2}\right)$, total surface area of salt marshes and mangroves $\left(0.384 \times 10^{6} \mathrm{~km}^{2}\right)$, and the FAO (2003) estimate of mangroves $\left(0.147 \times 10^{6} \mathrm{~km}^{2}\right)$.

The potential emission of $\mathrm{CO}_{2}$ from inner estuaries can be roughly estimated indirectly from a mass balance of terrestrial/ riverine organic carbon. Assuming an input of terrestrial/riverine particulate organic carbon (POC) ranging from $0.17 \mathrm{PgC}^{-1}$ (Ludwig et al., 1996) to $0.50 \mathrm{PgC}^{-1}$ (Richey, 2004), and the degradation of POC during estuarine transit ranging from $50 \%$ (Abril et al., 2002) to 70\% (Keil et al., 1997), we compute a potential emission of $\mathrm{CO}_{2}$ from POC degradation by inner estuaries ranging from 0.09 to $0.35 \mathrm{PgC} \mathrm{yr}^{-1}$. Assuming a $10 \%$ removal of river dissolved organic carbon (DOC) during estuarine transit (Moran et al., 1999; Raymond and Bauer, 2000; Wiegner and Seitzinger, 2001), and the global DOC input of $0.21 \mathrm{PgC} \mathrm{yr}^{-1}$ (Ludwig et al., 1996) brings the potential emission of $\mathrm{CO}_{2}$ from total organic carbon (TOC) removal by inner estuaries to a range between 0.11 and $0.37 \mathrm{PgCyr}^{-1}$. If the emission of $\mathrm{CO}_{2}$ due to ventilation of riverine $\mathrm{CO}_{2}$ of $10 \%$ (Borges et al., 2006) is added, the overall potential emission of $\mathrm{CO}_{2}$ by inner estuaries ranges from 0.12 to $0.41 \mathrm{PgC} \mathrm{yr}^{-1}$.

The $\mathrm{CO}_{2}$ emission by inner estuaries based on $\mathrm{pCO}_{2}$ measurements falls within the range of values estimated by mass balance, but is nevertheless 3-fold higher than the lowest estimate from the mass-balance computations. As discussed in detail by Abril and Borges (2004) and Borges (2005), the value of inner estuary surface area given by Woodwell et al. (1973) is probably overestimated. Also noteworthy is that most available data were obtained in macro-tidal estuaries, which have a vertically mixed water column and a long residence time. These physical characteristics promote TOC degradation with subsequent emission of $\mathrm{CO}_{2}$ to the atmosphere compared to other ecotypes of estuaries such as micro-tidal estuaries (Borges, 2005). This is illustrated by the fact that the only system reported in Table 1 that behaves as a net annual sink for atmospheric $\mathrm{CO}_{2}$ is the Aby lagoon, which is a permanently stratified system with a long residence time of the water mass, allowing the sedimentation of organic carbon across the pycnocline, making the upper mixed layer an effective carbon sink (Koné et al., 2009).

\section{Air-sea $\mathrm{CO}_{2}$ fluxes in continental shelves}

Tsunogai et al. (1999) coined the term "continental shelf pump", which would account for a net uptake of $\mathrm{CO}_{2}$ of $1.0 \mathrm{PgC}^{-1}$, if the world continental shelves would absorb atmospheric $\mathrm{CO}_{2}$ at the same rate computed from data obtained from a single transect in the East China Sea. This value, however, is almost certainly an overestimate, as more recent studies in the East China Sea have yielded lower fluxes. Indeed, based on $\mathrm{pCO}_{2}$ data from several cruises, Chen and Wang (1999) computed an airto-sea flux of $2.0 \mathrm{~mol} \mathrm{C} \mathrm{m}^{-2} \mathrm{yr}^{-1}$, lower than the value of $3.0 \mathrm{~mol}$ $\mathrm{C} \mathrm{m}^{-2} \mathrm{yr}^{-1}$ estimated by Chen and Tsunogai (1998) and Tsunogai et al. (1999). This points out the need for high-resolution coverage, both temporal and spatial, to provide robust and unbiased estimates of $\mathrm{CO}_{2}$ air-sea fluxes in continental shelves.

Another example is the air-sea $\mathrm{CO}_{2}$ flux estimates in the US South Atlantic Bight (SAB); based on five cruises Cai et al. (2003) estimated that the $\mathrm{SAB}$ was a strong source of $\mathrm{CO}_{2}$ to the atmosphere at a rate of $2.5 \mathrm{~mol} \mathrm{C} \mathrm{m}^{-2} \mathrm{yr}^{-1}$, but based on six cruises, Jiang et al. (2008b) recently reported that the SAB is a sink for atmospheric $\mathrm{CO}_{2}$ at a rate of $0.5 \mathrm{~mol} \mathrm{C} \mathrm{m}^{-2} \mathrm{yr}^{-1}$. The difference between these two studies is that Cai et al. (2003) obtained their $\mathrm{pCO}_{2}$ data along one single linear transect perpendicular to the coast, while Jiang et al. (2008b) surveyed the entire SAB, providing the necessary spatial coverage required to produce a robust estimate of air-sea $\mathrm{CO}_{2}$ fluxes. Besides covering adequately the spatial heterogeneity, high temporal coverage is also required to estimate reliably air-sea $\mathrm{CO}_{2}$ fluxes in highly dynamic coastal environments.

For instance, Thomas et al. (2004) reported that the Southern Bight of the North Sea (SBNS) was a source of $\mathrm{CO}_{2}$ at a rate of $0.2 \mathrm{~mol} \mathrm{C} \mathrm{m}^{-2} \mathrm{yr}^{-1}$. More recently, Schiettecatte et al. (2007) showed that the SBNS is actually a sink for atmospheric $\mathrm{CO}_{2}$ at a rate of $0.7 \mathrm{~mol} \mathrm{C} \mathrm{m}^{-2} \mathrm{yr}^{-1}$. Both the Thomas et al. (2004) and Schiettecatte et al. (2007) studies covered satisfactorily the spatial variability of the SBNS but the first estimate was based on only four cruises while the second was based on 10 cruises. The disagreement in net annual $\mathrm{CO}_{2}$ flux estimates between the two studies is due to the fact that the "spring cruise" of the data set of Thomas et al. (2004) was carried out in May, during the declining phase of the phytoplankton bloom, implying that this data set did not adequately account for the strong $\mathrm{CO}_{2}$ under-saturation in the SBNS typically observed in mid-April (Borges and Frankignoulle, 1999, 2002a) during the peak of the phytoplankton bloom.

In absence of long time-series of $\mathrm{pCO}_{2}$ measurements in continental shelves, a not quantified potential bias in air-sea $\mathrm{CO}_{2}$ flux estimates relates to inter-annual variability and long-term changes. In the California upwelling system, Friederich et al. (2002) reported a shift from an annual source to an annual sink of $\mathrm{CO}_{2}$ due to the El Niño Southern Oscillation. Strong inter-annual variability in the sink of $\mathrm{CO}_{2}$ in Tasman continental shelf has been recently reported due to changes in mixing related to the Southern Annular Mode (Borges et al., 2008). In coastal areas in the vicinity of the Bering and Okhotsk Seas a long-term increase in the sink of $\mathrm{CO}_{2}$ has been reported (Takahashi et al., 2006), while in the North Sea a long-term decrease in the sink of $\mathrm{CO}_{2}$ has been reported (Thomas et al., 2007). The causes of these long-term trends remain unclear.

During the past few years, the number of studies reporting air-sea $\mathrm{CO}_{2}$ fluxes based on $\mathrm{pCO}_{2}$ measurements worldwide has significantly increased, amounting to about 60 continental shelves listed in Table 2 according to the season, which also includes the annual average flux when available. The histogram of daily $\mathrm{CO}_{2}$ fluxes during the different seasons is shown in Fig. 1. Although there is a large scatter, most studies report that the continental shelves are sinks for atmospheric $\mathrm{CO}_{2}$ during most of the seasons. In spring, 14 studies reported that there is a net sink of $\mathrm{CO}_{2}$ while only 4 reported a source of $\mathrm{CO}_{2}$. In summer, a higher number of studies (25) reported a source of $\mathrm{CO}_{2}$ to the atmosphere compared with 12 studies reporting otherwise. This is probably due to the thermodynamic increase of $\mathrm{pCO}_{2}$ due to warming of surface waters, and due to the degradation of organic matter produced during the spring bloom. The surface seawater temperature starts to decrease in autumn, inducing a drop in $\mathrm{pCO}_{2}$ values because of the change in the $\mathrm{CO}_{2}$ solubility coefficient. As a result, marginal seas tend to be $\mathrm{CO}_{2}$ sinks in autumn and winter.

Overall, the number of studies that reported continental shelves as $\mathrm{CO}_{2}$ sinks outweigh those that reported continental shelves as $\mathrm{CO}_{2}$ sources. Because of the small number of observations for each season, the distribution is not normal. The annually integrated $\mathrm{CO}_{2}$ fluxes, however, show a more normal distribution, and the numerical average is $\sim 1.1 \mathrm{~mol} \mathrm{C} \mathrm{m}^{-2} \mathrm{yr}^{-1}$. This value, if scaled to the global surface area of continental shelves of $26 \times 10^{6} \mathrm{~km}^{2}$, yields an annual $\mathrm{CO}_{2}$ uptake of about $29 \times 10^{12} \mathrm{~mol} \mathrm{Cyr}^{-1}\left(0.35 \mathrm{PgC} \mathrm{yr}^{-1}\right)$. 
Table 2

Air-sea fluxes of $\mathrm{CO}_{2}$ in various continental margins ${ }^{\mathrm{a}}$.

\begin{tabular}{|c|c|c|c|c|c|c|}
\hline Area & $\begin{array}{l}\text { Spring } \\
\left(\mathrm{mmol} \mathrm{m}^{-2} \mathrm{~d}^{-1}\right)\end{array}$ & $\begin{array}{l}\text { Summer } \\
\left(\mathrm{mmol} \mathrm{m}^{-2} \mathrm{~d}^{-1}\right)\end{array}$ & Fall $\left(\mathrm{mmol} \mathrm{m}^{-2} \mathrm{~d}^{-1}\right)$ & Winter $\left(\mathrm{mmol} \mathrm{m}^{-2} \mathrm{~d}^{-1}\right)$ & $\begin{array}{l}\text { Annual } \\
\left(\mathrm{mol} \mathrm{Cm}^{-2} \mathrm{yr}^{-1}\right)\end{array}$ & References \\
\hline Amazon River Plume & & & & & $0.5-1.7$ & Ternon et al. (2000), Körtzinger (2003) \\
\hline Antarctic Shelves & & $11-34^{1}$ & & & $2.2^{2}$ & $\begin{array}{l}\text { 1. Chen et al. (2004a, b); 2. Carrillo and } \\
\text { Karl (1999) }\end{array}$ \\
\hline Arabian Sea & & & & & -0.9 & Goyet et al. (1998) \\
\hline Arctic Sea & & & & & $0.21^{1}, 0.51^{2}$ & $\begin{array}{l}\text { 1. Anderson and Jones (1981), Anderson } \\
\text { et al. (1990); 2. Bates (2006) }\end{array}$ \\
\hline Shelves & & & & & 0.14 & Anderson et al. (1998) \\
\hline Atlantic Bight & & & & & $0.5-1.3$ & DeGrandpre et al. (2002) \\
\hline Baffin Bay & $\sim 0.3$ & 0.45 & $\sim 0.3$ & $\sim 0$ & 0.43 & Miller et al. (2002) \\
\hline Baltic Sea & & & & & $0.9^{1}, 3.0^{2}$ & $\begin{array}{l}\text { 1. Thomas et al. (2008); } 2 \text {. Kuss et al. } \\
\text { (2006) }\end{array}$ \\
\hline Barrents Sea & & $2.7^{1}$ & & & $0.55^{2}, 3.6^{3}$ & $\begin{array}{l}\text { 1. Kaltin et al. (2002); 2. Fransson et al. } \\
\text { (2001); 3. Borges et al. (2005) }\end{array}$ \\
\hline Bay of Bengal & & & & & -0.4 & Goyet et al. (1998) \\
\hline Beaufort Shelves & & $2.9^{1}$ & & & $1.2^{2}$ & $\begin{array}{l}\text { 1. Murata and Takizawa (2003); } 2 \text {. Cai et } \\
\text { al. (2006) }\end{array}$ \\
\hline Benguela Current & 11 & & & 5.5 & $0-1^{1}, 1.62^{2}$ & $\begin{array}{l}\text { 1. P. Monterio, personal communication } \\
\text { (2007) } \\
\text { 2. Santana-Casiano and González-Dávila } \\
\text { (2009) }\end{array}$ \\
\hline Bering Sea Basin & & & & & -4.7 & Fransson et al. (2006) \\
\hline Bering Sea Shelf & $1.2^{1}$ & $0.66^{2}$ & & & $4.3^{3}$ & $\begin{array}{l}\text { 1.Nedashkovsky et al. (1995); } 2 \text {. } \\
\text { Codispoti et al. (1986); 3. Walsh and } \\
\text { Dieterle (1994) }\end{array}$ \\
\hline Black Sea & & 20 & & & & Goyet et al. (1991) \\
\hline Brazil Shelf & $-9.8^{1}$ & $-4.2^{1}$ & & $-0.3^{1}$ & $-1.8^{2}$ & 1. Ito et al. (2005); 2. Borges et al. (2005) \\
\hline Bristol Bay & & & & & 0.2 & Borges et al. (2005) \\
\hline California Coast & & & & & -2.2 to -0.7 & Friederich et al. (2002) \\
\hline Chukchi Sea & $<0.1-1^{5}$ & $2.9^{1}, 13-52^{2,3}, 30-90^{5}$ & $12^{4}$ & & $4.8^{5}, 3.1^{6}$ & $\begin{array}{l}\text { 1.Murata and Takizawa (2003); 2. Wang } \\
\text { et al. (2003); 3. Li et al. (2004); 4. Pipko } \\
\text { et al. (2002); 5. Bates (2006); 6. Kaltin } \\
\text { and Anderson (2005) }\end{array}$ \\
\hline E. China Sea & $\begin{array}{l}1.66^{1}, 2.1 \pm 2.8^{2}, 1.8^{3} \\
5.04 \pm 1.59^{9}\end{array}$ & $1.2^{3},-2.52 \pm 1.81^{9}$ & $-0.65^{1}, 2.0^{3}, 1 \pm 3^{9}$ & $3.1^{3}$ & $\begin{array}{l}2.1^{3}, 3.3^{4}, 2(1.1-2.5)^{5} \\
3^{6}, 1^{7}, 0.03^{8}\end{array}$ & $\begin{array}{l}\text { 1. Ma et al. (1999); 2. Peng et al. (1999); } \\
\text { 3. Wang et al. (2000); 4. Tsunogai et al. } \\
\text { (1997); 5. Chen and Wang (1999); } 6 \text {. } \\
\text { Tsunogai et al. (1999); 7. Zhang et al. } \\
\text { (1999); 8. Zhang (1999); 9. Shim et al. } \\
\text { (2007) }\end{array}$ \\
\hline E. Mediterranean & & & & & $0.78-4 \times 10^{-4}$ & de Madron et al. (2008) \\
\hline Ecuador-Chile & & & & & -0.6 & Cai et al. (2006) \\
\hline English Channel & & & & & $0^{1},-0.3^{2}$ & $\begin{array}{l}\text { 1. Borges and Frankignoulle, 2003; } 2 . \\
\text { Thomas et al. (2008) }\end{array}$ \\
\hline Funka Bay (Japan) & & & & & $\begin{array}{l}\text { Mean } \\
\Delta \mathrm{pCO}_{2}=-75 \mu \mathrm{atm}\end{array}$ & Nakayama et al. (2000) \\
\hline Galician Coast & & & & & 2.2 & Borges et al. (2005) \\
\hline Gulf of Biscay & 2.01 & 5.51 & 0.51 & -0.31 & $1.7-2.91$ & Frankignoulle and Borges (2001) \\
\hline Gulf of California & & -5.4 & & & & Hidalgo-González et al. (1997) \\
\hline Gulf of Cadiz & & -18.6 & & & & Ait-Ameur and Goyet (2006) \\
\hline Gulf of Lion & & & & & 7.1 & de Madron et al. (2008) \\
\hline Gulf of Mexico Shelf & & $2-4.2^{1}$ & & & $0.5^{2}$ & $\begin{array}{l}\text { 1.Lohrenz and Cai, 2006; 2.Cai et al., } \\
2006\end{array}$ \\
\hline Hudson Bay & & 3.9 & & & & Else et al. (2008) \\
\hline Iberian & $0.4^{1}$ & $-0.07^{1}, 4.5^{2}$ & $0.2^{1}, 0.9^{2}$ & & $1.6(1.3-2.6)^{2}$ & $\begin{array}{l}\text { 1.Pérez et al. (1999); 2. Borges and } \\
\text { Frankignoulle (2002a, b) }\end{array}$ \\
\hline Japan Sea & & & & & 3.8 & Cai et al. (2006), Kang et al. (2008) \\
\hline
\end{tabular}




\begin{tabular}{|c|c|c|c|c|c|c|}
\hline Jiaozhou Bay & -9.4 & -22.2 & -10.8 & 1.9 & -3.7 & Li et al. (2007) \\
\hline Kara Sea & & & & & 0.011 & Fransson et al. (2001) \\
\hline Laptev Sea & & & & & 0.011 & Fransson et al. (2001) \\
\hline Mediterranean Sea & & & & & $0.52-2.8 \times 10^{-4}$ & de Madron et al. (2008) \\
\hline New Jersey Coast & $>0$ & $<0$ & $<0$ & $\gg 0$ & $0.44-0.84$ & Boehme et al. (1998) \\
\hline NE Greenland & & 1.3 & & & & Yager et al. (1995) \\
\hline North Sea & $14^{1}$ & $13^{1}, 1.4^{2}$ & $-0.9^{1}$ & & $1.3^{3}, 1.5-2.2^{4} 1.38^{5}$ & $\begin{array}{l}\text { 1. Frankignoulle and Borges (2001); } 2 \text {. } \\
\text { Kempe and Pegler (1991); } 3 \text {. Thomas et } \\
\text { al. (2008); } 4 \text {. Bozec et al. (2005); } 5 \text {. } \\
\text { Thomas et al. (2005) }\end{array}$ \\
\hline Nova Scotia, Maine & & & & & 0.7 & Cai et al. (2006) \\
\hline Okhotsk Sea & & 2.7-5.5 (May-Sept.) ${ }^{1}$ & & & $2.5^{2}, 0.83^{3}$ & $\begin{array}{l}\text { 1. Chen et al. (2003); 2. Otsuki et al. } \\
\text { (2003); 3. Wakita et al. (2003) }\end{array}$ \\
\hline Omani Coast & & & & & -2.5 & Goyet et al. (1998) \\
\hline Oregon Coast & & 20 & & & & Hales et al. (2005) \\
\hline Patagenian Shelf & & & & & 1.5 & Bianchi et al. (2005) \\
\hline Prydz Bay & & $75^{1}$ & & & $2.2^{2}$ & $\begin{array}{l}\text { 1. Wang et al. (1998); } 2 \text {. Borges et al. } \\
\text { (2005) }\end{array}$ \\
\hline Ross Sea & & $25^{1}, 4-10^{2}$ & & & $1.5^{3}, 0.07-1.55^{4}$ & $\begin{array}{l}\text { 1. Wang et al. (1998); 2. Bates et al. } \\
\text { (1998); 3. Borges et al. (2005); } 4 \text {. Arrigo } \\
\text { and Van Dijken (2007) }\end{array}$ \\
\hline S. Atlantic Bight & & & & & -2.5 & Cai et al. (2003) \\
\hline S. China Sea & & $4.8^{1},-0.73^{2}$ & & $0.5^{2}$ & $-0.18^{2}, 1.0^{3},-1.3^{4}$ & $\begin{array}{l}\text { 1. Rehder and Suess (2001); } 2 \text {. Chen et al. } \\
\text { (2006a, b); } 3 \text {. Chen et al. (2003); } 4 \text {. Zhai } \\
\text { et al. (2005) }\end{array}$ \\
\hline Strait of Gibraltar & $5.5 \pm 2$ & $-3 \pm 8$ & & $19 \pm 6$ & 2.5 & Santana-Casiano et al. (2002) \\
\hline Sulu Sea & & & & & & Chen et al. (2006b) \\
\hline Taiwan St. & 17.6 & & & & & Ma et al. (1999) \\
\hline Tasmania & $7.14^{\mathrm{c}}$ & $7.09^{c}$ & $6.21^{\mathrm{c}}$ & $5.14^{\mathrm{c}}$ & 2.3 & Borges et al. (2008) \\
\hline Vancouver Is. Coast & & & & & 1.2 & Borges et al. (2005) \\
\hline W. European Shelves & $1.1-18.3$ & $3.4-24.4$ & $0.4-2.4$ & $-0.5 \sim-0.9$ & $4.8-7.9$ & Frankignoulle and Borges (2001) \\
\hline Weddell Sea & & $-0.3^{\mathrm{c}}$ & & & & Stoll et al. (2002) \\
\hline W. Florida Shelf & & & & & $\begin{array}{l}\Delta \mathrm{pCO}_{2}=-43 \text { to } \\
-64 \mu \mathrm{atm}\end{array}$ & Wanninkhof et al. (1997) \\
\hline W. Mediterranean & $<0$ & $\gg 0$ & $>0$ & $<0$ & $\begin{array}{l}0.5 \pm 0.18 \\
1.5-8 \times 10^{-4}\end{array}$ & $\begin{array}{l}\text { Begovic and Copin-Montégut (2002) } \\
\text { de Madron et al. (2008) }\end{array}$ \\
\hline & & & & 4 & & Copin-Montégut and Bégovic (2002) \\
\hline Yellow Sea & $4.4^{1}$ & $-1.8^{1}$ & $4.4^{1}$ & $13^{1}$ & $2.4^{1}, 2 \pm 0.7^{2}$ & 1.Oh et al. (2000); 2. Wang et al. (2001) \\
\hline Global Coral Reefs $\left(0.6 \times 10^{6} \mathrm{~km}^{2}\right)$ & $>0^{1},<0^{2}$ & $<0^{3}$ & $\sim 0^{2}$ & $>0^{3}$ & $\begin{array}{l}-0.1 \text { to }-3.2^{4},-1.1 \text { to } \\
-2.6^{5}\end{array}$ & $\begin{array}{l}\text { 1. Smith (1973); 2. Kawahata et al. } \\
\text { (1999); 3. Kayanne et al. (2005); } 4 \text {. } \\
\text { Borges et al. (2005); 5. Frankignoulle et } \\
\text { al. (1996) }\end{array}$ \\
\hline Global Coastal (to $\sim 40 \mathrm{~m}$ depth) & & & & & -1.8 & Rabouille et al. (2001) \\
\hline Global Shelves ( $\sim 40 \mathrm{~m}-200 \mathrm{~m}$ depth) & & & & & & Rabouille et al. (2001) \\
\hline GLOBAL & & & & & $\begin{array}{l}2.2^{1}, 2.4^{2}, 0.3^{3}, 1.9^{4}, 1^{5} \\
1.8-2.0^{6}, 1.15^{7}, 1.17^{8} \\
1.62^{9}, 0.72^{10}\end{array}$ & $\begin{array}{l}\text { 1. Sabine and Mackenzie (1991a, b); } 2 \text {. } \\
\text { Walsh and Dieterle (1994); 3. Liu et al. } \\
\text { (2000); 4. Yool and Fasham (2001); } 5 \text {. } \\
\text { Chen et al. (2003); 6. Ducklow and } \\
\text { McCallister (2004); 7. Chen (2004); } 8 \text {. } \\
\text { Borges (2005); 9. Borges et al. (2005); } \\
\text { 10. Cai et al. (2006) }\end{array}$ \\
\hline
\end{tabular}

a The most recent values are used, a positive flux is directed from air to sea, a negative flux is directed from sea to air.

b Spring: March-May; Summer: June-August; Fall: September-November; Winter: December-February.

Austral seasons. 

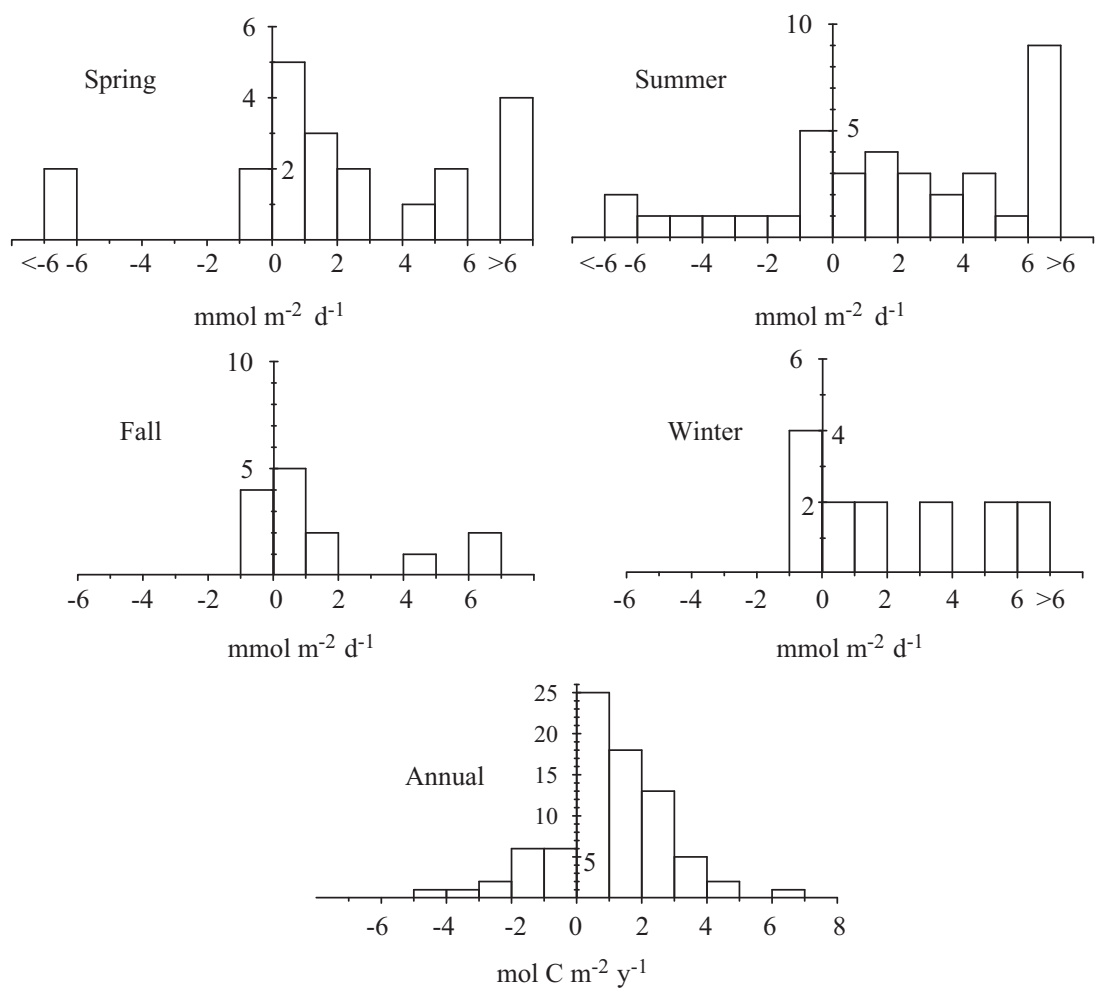

Fig. 1. Histogram of reported daily fluxes of $\mathrm{CO}_{2}$ during different seasons as well as the annual flux.

Fig. 2 shows the histogram of reported daily fluxes of $\mathrm{CO}_{2}$ by different latitude bands. High-latitude and temperate continental shelves are sinks for atmospheric $\mathrm{CO}_{2}$, while tropical and subtropical shelves tend to act as sources of $\mathrm{CO}_{2}$ to the atmosphere. This latitudinal variability in air-sea $\mathrm{CO}_{2}$ fluxes is related to the fact that biological activity over continental shelves modulates a background $\mathrm{CO}_{2}$ signal imposed by oceanic waters circulating over the continental shelf. Open oceanic waters are generally undersaturated in $\mathrm{CO}_{2}$ at high- and mid-latitudes (Takahashi et al., 2002, 2009), where continental shelves are highly productive (e.g., Walsh, 1988), hence increasing the background open-ocean $\mathrm{CO}_{2}$ under-saturation. At sub-tropical and tropical latitudes open oceanic waters are generally over-saturated in $\mathrm{CO}_{2}$ (Takahashi et al., 2002, 2009), and non-upwelling continental margins are less productive, tending to be oligotrophic (e.g. Walsh, 1988), and receive massive inputs of terrestrial organic matter (up to $60 \%$ of the global TOC river inputs, e.g., Ludwig et al., 1996), leading to an enhancement of the background open ocean $\mathrm{CO}_{2}$ over-saturation.

Continental shelves were divided into various biogeochemical regions (Polar, Subpolar, Western Boundary Current, Eastern Boundary Current, Tropical and Monsoonal) for each ocean basin following the classification of Jahnke (2009), and we scaled the air-sea $\mathrm{CO}_{2}$ fluxes for the 27 regions (Table 3) based on the air-sea $\mathrm{CO}_{2}$ fluxes compiled in Table 2. The scaled $\mathrm{CO}_{2}$ fluxes by biogeochemical provinces yield a $\mathrm{CO}_{2}$ sink of $27.3 \times 10^{12} \mathrm{~mol} \mathrm{C}$ $\mathrm{yr}^{-1}\left(0.33 \mathrm{PgC} \mathrm{yr}^{-1}\right.$ or $\left.0.91 \mathrm{~mol} \mathrm{C} \mathrm{m}^{-2} \mathrm{yr}^{-1}\right)$ for a total continental shelf area of $30 \times 10^{6} \mathrm{~km}^{2}$, in agreement with the $\mathrm{CO}_{2}$ sink based on the scaled numerical average of $0.35 \mathrm{PgCyr}^{-1}$ (or $1.1 \mathrm{molC}$ $\mathrm{m}^{-2} \mathrm{yr}^{-1}$ ) given above for a smaller area. The largest contributions to this sink of $\mathrm{CO}_{2}$ are from subpolar and polar biogeochemical provinces, respectively, 17.9 and $12.1 \times 10^{12} \mathrm{~mol} \mathrm{C} \mathrm{yr}^{-1}$. Monsoonal and tropical biogeochemical provinces act as moderate $\mathrm{CO}_{2}$ sources of similar amount, respectively, 0.5 and $0.3 \times 10^{12} \mathrm{~mol} \mathrm{C}$ $\mathrm{yr}^{-1}$. Eastern Boundary Current and Western Boundary Current biogeochemical provinces act, respectively, as a $\mathrm{CO}_{2}$ sink $\left(1.2 \times 10^{12} \mathrm{~mol} \mathrm{Cyr}^{-1}\right)$ and as a $\mathrm{CO}_{2}$ source $\left(3.1 \times 10^{12} \mathrm{~mol} \mathrm{Cyr}^{-1}\right)$.

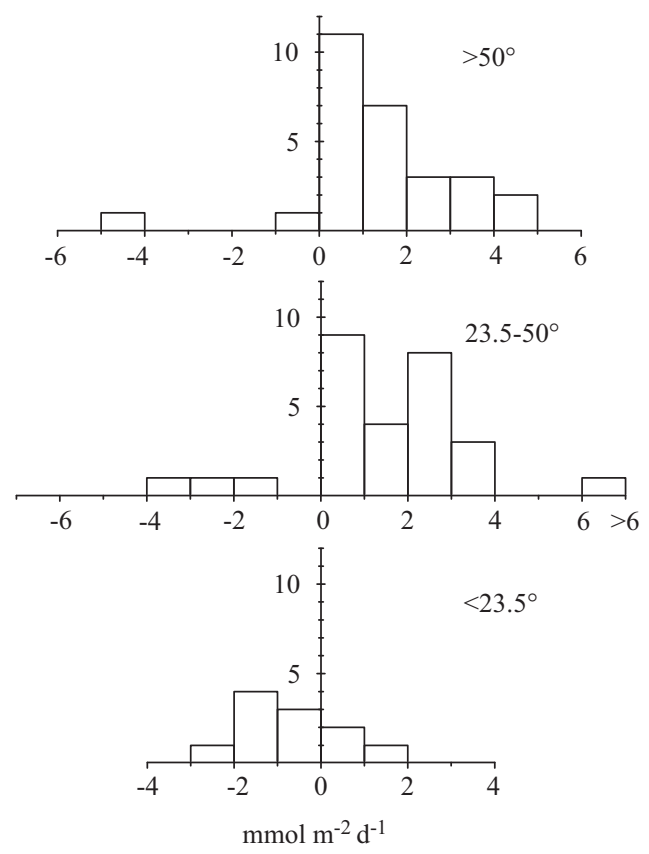

Fig. 2. Histogram of reported annual fluxes of $\mathrm{CO}_{2}$ in different latitudinal bands.

Note that some western boundary current systems act as $\mathrm{CO}_{2}$ sinks, namely those located in Atlantic Ocean basin (Arístegui et al., 2005) such as the Galician upwelling system (Borges and Frankignoulle, 2002b) and the Benguela upwelling system (Santana-Casiano and González-Dávila, 2009). Among the ocean basins, the largest coastal $\mathrm{CO}_{2}$ sink is for the Atlantic Ocean $\left(8.4 \times 10^{12} \mathrm{~mol} \mathrm{C} \mathrm{yr}^{-1}\right)$ due to its large surface area $\left(12.8 \times 10^{6} \mathrm{~km}^{2}\right.$, $42.6 \%$ of total continental shelf surface area), followed by the Arctic Ocean $\left(7.7 \times 10^{12} \mathrm{~mol} \mathrm{Cyr}^{-1}\right)$ due to large areal $\mathrm{CO}_{2}$ fluxes $\left(2.2 \mathrm{~mol} \mathrm{C} \mathrm{m}^{-2} \mathrm{yr}^{-1}\right.$ compared to $0.7 \mathrm{~mol} \mathrm{C} \mathrm{m}^{-2} \mathrm{yr}^{-1}$ in the Atlantic 
Table 3

Air-sea exchanges of $\mathrm{CO}_{2}$ in continental shelves by biogeochemical provinces and ocean basins.

\begin{tabular}{|c|c|c|c|c|}
\hline Region & Biogeochemical province & $\operatorname{Area}^{\mathrm{a}}\left(10^{6} \mathrm{~km}^{2}\right)$ & $\begin{array}{l}\text { Air-sea flux } \\
\left(\mathrm{mol} \mathrm{CO}_{2} \mathrm{~m}^{-2} \mathrm{yr}^{-1}\right)\end{array}$ & $\begin{array}{l}\text { Total air-sea exchange } \\
\left(10^{12} \mathrm{~mol} \mathrm{CO}_{2} \mathrm{yr}^{-1}\right)\end{array}$ \\
\hline Arctic & Polar & 3.51 & 2.2 & 7.72 \\
\hline Antarctic & Polar & 2.19 & 2.0 & 4.38 \\
\hline NW Atlantic & Subpolar & 2.25 & 1.0 & 2.25 \\
\hline NW Atlantic & Western Boundary Current & 1.54 & -0.5 & -0.77 \\
\hline W Atlantic & Tropical & 0.62 & -0.1 & -0.06 \\
\hline SW Atlantic & Western Boundary Current & 1.68 & -1.0 & -1.68 \\
\hline SW Atlantic & Subpolar & 2.33 & 1.5 & 3.50 \\
\hline NE Atlantic & Subpolar & 2.34 & 1.6 & 3.74 \\
\hline NE Atlantic & Eastern Boundary Current & 1.68 & 0.8 & 1.34 \\
\hline E Atlantic & Tropical & 0.18 & -0.1 & -0.02 \\
\hline SE Atlantic & Eastern Boundary Current & 0.22 & 0.5 & 0.11 \\
\hline Atlantic Subtotal & & 12.84 & 0.66 (ave.) & 8.41 \\
\hline W Indian & Monsoonal & 0.50 & -1.4 & -0.70 \\
\hline W Indian & Tropical & 0.08 & -0.1 & -0.01 \\
\hline W Indian & Western Boundary Current & 0.18 & -1.0 & -0.18 \\
\hline E Indian & Monsoonal & 0.62 & 0.4 & 0.25 \\
\hline E Indian & Tropical & 0.23 & -0.1 & -0.02 \\
\hline E Indian & Eastern Boundary Current & 0.25 & -0.1 & -0.02 \\
\hline E Indian & Subpolar & 0.38 & 1.8 & 0.68 \\
\hline Indian Subtotal & & 2.24 & 0.00 (ave.) & 0.00 \\
\hline NW Pacific & Subpolar & 2.91 & 2.5 & 7.28 \\
\hline NW Pacific & Western Boundary Current & 1.36 & 1.1 & 1.50 \\
\hline W Pacific & Tropical & 2.15 & -0.1 & -0.22 \\
\hline SW Pacific & Western Boundary Current & 2.01 & -1.0 & -2.01 \\
\hline NE Pacific & Subpolar & 0.22 & 1.8 & 0.40 \\
\hline NE Pacific & Eastern Boundary Current & 0.40 & -0.5 & -0.20 \\
\hline E Pacific & Tropical & 0.10 & -0.1 & -0.01 \\
\hline SE Pacific & Eastern Boundary Current & 0.20 & -0.1 & -0.02 \\
\hline SE Pacific & Subpolar & 0.03 & 1.8 & 0.05 \\
\hline Pacific subtotal & & 9.38 & 0.72 (ave.) & 6.77 \\
\hline Grand totals & & 30.16 & 0.90 (ave.) & 27.28 \\
\hline
\end{tabular}

a Taken from Jahnke (2009).

and Pacific Oceans). The Pacific Ocean and the Antarctic Ocean also significantly contribute 6.8 and $4.4 \times 10^{12} \mathrm{~mol} \mathrm{Cyr}^{-1}$, respectively, to the global continental shelf $\mathrm{CO}_{2}$ sink, while the Indian Ocean continental shelf has a nearly neutral status with regards to the $\mathrm{CO}_{2}$ exchange between the continental shelf and the atmosphere.

\section{Carbon mass balance}

The global carbon pools can be divided into several compartments, representing the atmosphere, rivers, shelf and slope waters, sediments, upper-ocean and deep-ocean organic carbon (both dissolved and particulate) as well as upper-ocean and deepocean inorganic carbon (Fig. 3). Fluxes among these compartments must balance each other out in order to conserve mass. In fact, the crux of the so-called Box Model is that the mass of various elements must be in balance even though the chemical forms of the elements under study may change, e.g., DOC may be oxidized to DIC.

As the amount of carbon entering the coastal ocean must equal the amount leaving it, values of $C$ fluxes across the air-sea interface can thus be constrained based on various known inputs, offshore exports and burial across other boundaries on the shelves. Most of these fluxes were tabulated in Chen et al. (2003) based on 27 studies. Chen (2004) made slight modifications to the box model of Chen et al. (2003) mainly because of a better quantification of new productivity on continental shelves taking into account DOC (Hansell and Carlson, 1998) in addition to POC production. Further, on account of the lower DOC values reported in subsurface waters in the open oceans in recent years, the flux of DOC from the open ocean to the shelves is reduced.

Fig. 3 is a schematic diagram summarizing the fluxes across boundaries, as indicated by various arrows. Values in the "shelves" box are for various species derived from primary and new production. There is a net off shelf transport of $50 \times 10^{12} \mathrm{~mol}$

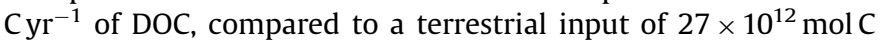

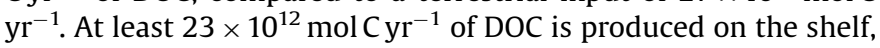
which represents $35 \%$ of new organic carbon production or $27 \%$ of the total new carbon production. A net air-to-sea flux of carbon is needed to support such an offshore transport of organic carbon. The net $\mathrm{CO}_{2}$ sink in continental shelves computed to close the budget is $0.36 \mathrm{PgC} \mathrm{yr}^{-1}$, close to values of 0.33 and $0.35 \mathrm{PgC} \mathrm{yr}^{-1}$ based on scaled estimates from $\mathrm{pCO}_{2}$ measurements given above.

As discussed earlier, some investigators have taken the view that the continental margins are net sources of $\mathrm{CO}_{2}$ to the atmosphere (Smith and Mackenzie, 1987; Smith and Hollibaugh, 1993; Ver et al., 1999a, b; Mackenzie et al., 2000; Fasham et al., 


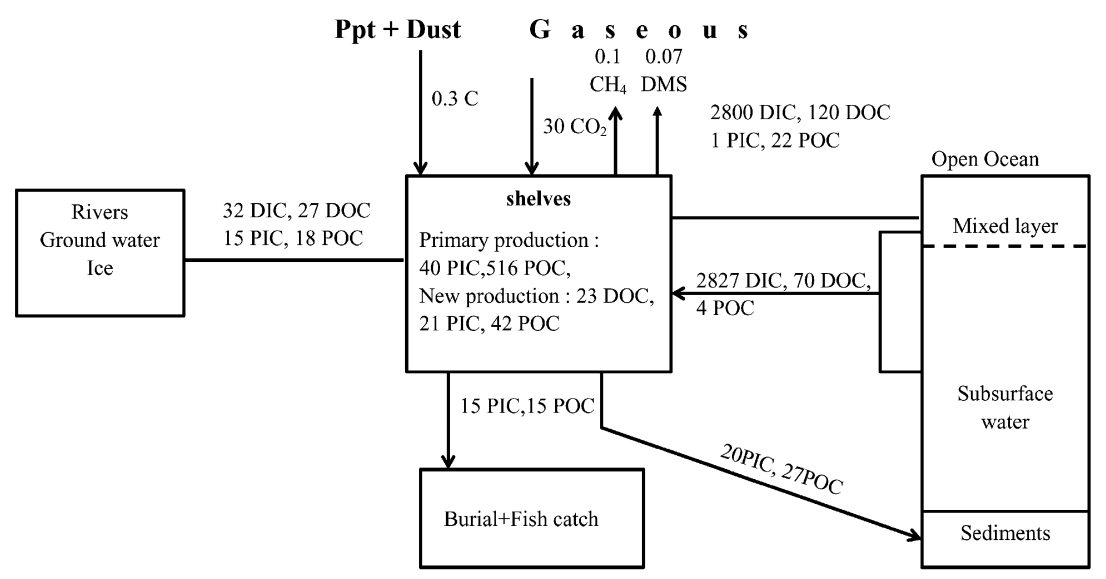

Fig. 3. Mass balance of carbon in continental shelves (flows are in $10^{12} \mathrm{~mol} \mathrm{C} \mathrm{yr}^{-1}$; modified from Chen, 2004).

2001). This view is based on the simple global mass balance of terrestrial/riverine organic carbon inputs and carbon burial in sediments (Smith and Mackenzie, 1987). However, terrestrial/ riverine organic carbon inputs are profoundly modified (and largely degraded) during estuarine transit based on the net heterotrophic ecosystem metabolic state of inner estuaries (Odum and Hoskin, 1958; Odum and Wilson, 1962; Heip et al., 1995; Kemp et al., 1997; Gattuso et al., 1998; Gazeau et al., 2004; Hopkinson and Smith, 2005), and based on organic carbon characterization both in the water column (e.g. Middelburg and Herman, 2007 and references therein) and sediments (Mayer et al., 2007 and references therein) of inner estuaries and nearshore coastal environments. Hence, inner estuaries and nearshore coastal ecosystems are effective filters for terrestrial/ riverine organic inputs and impose a by-pass of carbon towards the atmosphere for the global carbon cycle. This is in agreement with the large $\mathrm{CO}_{2}$ emission from inner estuaries we report and allows us to explain the apparent paradox that little terrestrial organic carbon can be accounted for in sediments or the water column of continental shelves and open oceanic waters based on tracer approaches (e.g. Hedges et al., 1997).

The view of a heterotrophic coastal ocean reported in earlier literature might have changed more recently. For instance, Yool and Fasham (2001) changed their view expressed in Fasham et al. (2001) and stated that, “... Results of simulations find modeled pump activity very variable between shelf regions, with the East China Sea shelf behaving very similarly to the global average", and "... should shelf regions absorb $\mathrm{CO}_{2}$ at the rate of the East China Sea, the pump would account for a net oceanic uptake of $0.6 \mathrm{PgCy}^{-1}$ ". Mackenzie and colleagues also recently changed their view on net $\mathrm{CO}_{2}$ fluxes in the coastal ocean. For instance, they stated in earlier papers that before anthropogenic activities, the global coastal ocean was a net autotrophic system with a net export of organic carbon to sediments and the open ocean of $20 \mathrm{~T} \mathrm{molC} \mathrm{yr}^{-1}$ (Ver et al., 1999a, b; Mackenzie et al., 2000). However, their later results (Rabouille et al., 2001) conclude that although the proximal coastal zones are $\mathrm{CO}_{2}$ sources $\left(8.4 \times 10^{12}\right.$ mol Cyr $\left.{ }^{-1}\right)$, the distal coastal zones are $\mathrm{CO}_{2}$ sinks $\left(28.4 \times 10^{12} \mathrm{~mol}\right.$ $\left(\mathrm{yr}^{-1}\right)$. As a result, the continental margins are found to be a net $\mathrm{CO}_{2}$ sink of $20 \times 10^{12} \mathrm{molCyr}^{-1}\left(0.24 \mathrm{PgCyr}^{-1}\right)$ in the preanthropogenic state, which differs from the $\mathrm{CO}_{2}$ source of $0.2{\mathrm{PgC} \mathrm{yr}^{-1}}^{-1}$ reported by Ver et al. (1999a, b) and Mackenzie et al. (2000).

In order to adjust the results of Ver et al. (1999a,b) and Mackenzie et al. (2000) with regard to the pre-anthropogenic $\mathrm{CO}_{2}$ fluxes, a correction of $0.44 \mathrm{PgC} \mathrm{yr}^{-1}$ needs to be made (to correct for a pre-anthropogenic source of $\mathrm{CO}_{2}$ of $0.20 \mathrm{PgC} \mathrm{yr}^{-1}$ given by Ver et al. (1999a, b) and Mackenzie et al. (2000), and so also for a pre-anthropogenic sink of $0.24{\mathrm{PgC} \mathrm{yr}^{-1}}$ given by Rabouille et al., 2001). As a consequence, this renders the continental margins as $\mathrm{CO}_{2}$ sinks of $0.34 \mathrm{PgC} \mathrm{yr}^{-1}$ in the present time (year 2000).

The carbon flows through the land/ocean/atmospheric system are far more complicated and diverse than the above simple algebra would suggest, but it is nevertheless worth underscoring the fact that the corrected air-sea $\mathrm{CO}_{2}$ flux of Ver et al. (1999a, b) and Mackenzie et al. (2000) of $0.34 \mathrm{PgCyr}^{-1}$ agrees with the values reported here ranging from 0.33 to $0.36 \mathrm{PgC} \mathrm{yr}^{-1}$ based on scaled $\mathrm{pCO}_{2}$ measurements and carbon mass balance in continental shelves.

\section{Conclusions}

The first LOICZ report asserted that whether coastal seas are net sinks or sources of $\mathrm{CO}_{2}$ could not be determined (Kempe, 1995). Based on carbon mass-balance calculations as well as scaled estimates based on $\mathrm{pCO}_{2}$ measurements, it is firmly established that most open shelf areas are sinks for atmospheric $\mathrm{CO}_{2}$, although many inner estuaries, near-shore coastal waters and intensive upwelling areas are over-saturated in $\mathrm{CO}_{2}$. On the whole, continental shelves are significant sinks for atmospheric $\mathrm{CO}_{2}$, ranging from 0.33 to $0.36 \mathrm{PgC} \mathrm{yr}^{-1}$, which corresponds to an additional sink of $27 \%$ to $\sim 30 \%$ of the $\mathrm{CO}_{2}$ uptake by the open oceans based on the most recent $\mathrm{pCO}_{2}$ climatology of Takahashi et al. (2009). On the other hand, inner estuaries, salt marshes and mangroves emit $\mathrm{CO}_{2}$ to the atmosphere of $\sim 0.50 \mathrm{PgC} \mathrm{yr}^{-1}$, although these estimates are prone to large uncertainty.

The concept of marginal seas as sinks and near-shore coastal ecosystems as sources of atmospheric $\mathrm{CO}_{2}$ allows reconciling diverging views on carbon cycling in the coastal ocean. The fact that the inputs of terrestrial/riverine organic carbon would be in excess of carbon burial in marine sediments (Smith and Mackenzie, 1987) does not necessarily imply a net heterotrophy of marginal seas that is in contradiction with the high offshore export rates of POC and DOC consistently reported across continental margins (e.g. overview by Chen, 2003; Liu et al., 2000). Also, tracer-based analysis of water column and sediment organic carbon in inner estuaries, continental shelves and open ocean confirm high removal rates of terrestrial organic carbon. Hence, inner estuaries and near-shore ecosystems are effective filters for terrestrial/riverine organic inputs and impose a by-pass of carbon towards the atmosphere for the global carbon cycle. 


\section{Acknowledgements}

Partial financial assistance from the ROC National Science Council (NSC 95-2621-Z-110-005 and 95-2621-M-110-001) and from IOCCP, SOLAS, IMBER and GCP is acknowledged. Two anonymous reviewers and Sylvie Roy provided valuable comments that strengthened the manuscript. This is a contribution to EU IP CARBOOCEAN (511176) and to EU Coordination and support action COCOS (212196). AVB is a research associate at the FNRS.

\section{References}

Abril, G., Borges, A.V., 2004. Carbon dioxide and methane emissions from estuaries In: Tremblay, A., Varfalvy, L., Roehm, C., Garneau, M. (Eds.), Greenhouse Gases Emissions from Natural Environments and Hydroelectric Reservoirs: Fluxes and Processes. Environmental Science Series. Springer, Berlin, Heidelberg, New York, pp. 187-207 (Chapter 7).

Abril, G., Etcheber, H., Delille, B., Frankignoulle, M., Borges, A.V., 2003. Carbonate dissolution in the turbid and eutrophic Loire estuary. Marine Ecology-Progress Series 259, 129-138.

Abril, G., Nogueira, E., Hetcheber, H., Cabeçadas, G., Lemaire, E., Brogueira, M.J., 2002. Behaviour of organic carbon in nine contrasting European estuaries. Estuarine, Coastal and Shelf Science 54, 241-262.

Aït-Ameur, N., Goyet, C., 2006. Distribution and transport of natural and anthropogenic $\mathrm{CO}_{2}$ in the Gulf of Cádiz. Deep-Sea Research II 53 (11-13) 1329-1343.

Algesten, G., Wikner, J., Sobek, S., Tranvik, L.J., Jansson, M., 2004. Seasonal variation of $\mathrm{CO}_{2}$ saturation in the Gulf of Bothnia: indications of marine net heterotrophy. Global Biogeochemical Cycles 18 (4), GB4021.

Anderson, L.G., Jones, E.P., 1981. Water masses and their chemical constituents in the western Nansen Basin of the Artic Ocean. Oceanology Acta 9, 277-283.

Anderson, L.G., Dyrssen, D., Jones, E.P., 1990. An assessment of the transport of atmospheric $\mathrm{CO}_{2}$ into Arctic Ocean. Journal of Geophysical Research 95 1703-1711.

Anderson, L.G., Olsson, K., Chierici, M., 1998. A carbon budget for the Arctic Ocean Global Biogeochemical Cycles 12 (3), 455-465.

Arístegui, J., Álvarez-Salgado, X.A., Barton, E.D., Figueiras, F.G., Hernández-León, S., Roy, C., Santos, A.M.P., 2005. Oceanography and fisheries of the Canary Current/ Iberian Region of the Eastern North Atlantic. In: Brink, K.H., Robinson, A.R (Eds.), The Sea, vol. 14. Wiley, New York, pp. 877-931.

Arrigo, K.R., Van Dijken, G.L., 2007. Interannual variation in air-sea $\mathrm{CO}_{2}$ flux in the Ross Sea, Antarctica: a model analysis. Journal of Geophysical Research 112, C03020.

Bates, N.R., 2006. Air-sea $\mathrm{CO}_{2}$ fluxes and the continental shelf pump of carbon in the Chukchi Sea adjacent to the Arctic Ocean. Journal of Geophysical Research 111, C10013.

Bates, N.R., Hansell, D.A., Carlson, C.A., 1998. Distribution of $\mathrm{CO}_{2}$ species, estimates of net community production, and air-sea $\mathrm{CO}_{2}$ exchange in the Ross Sea polynya. Journal of Geophysical Research 103, 2883-2896.

Begovic, M., Copin-Montégut, C., 2002. Processes controlling the annual variations of the partial pressure of $\mathrm{CO}_{2}$ in the surface water of the central part of the northwestern Mediterranean Sea (Dyfamed site). Deep-Sea Research II 49, 2031-2048.

Bianchi, A.A., Bianucci, L., Piola, A.R., Pino, D.R., Schloss, I., Poisson, A., Balestrini, C.F., 2005. Vertical stratification and air-sea $\mathrm{CO}_{2}$ fluxes in the Patagonian Shelf Journal of Geophysical Research 110, $\mathrm{C} 07003$

Boehme, S.E., Sabine, C.L., Reimers, C.E., 1998. $\mathrm{CO}_{2}$ fluxes form a coastal transect: a time series approach. Marine Chemistry 63, 49-67.

Borges, A.V., 2005. Do we have enough pieces of the jigsaw to integrate $\mathrm{CO}_{2}$ fluxes in the Coastal Ocean? Estuaries 28 (1), 3-27.

Borges, A.V., Frankignoulle, M., 1999. Daily and seasonal variations of the partial pressure of $\mathrm{CO}_{2}$ in surface seawater along Belgian and southern Dutch coastal areas. Journal of Marine Systems 19 (4), 251-266.

Borges, A.V., Frankignoulle, M., 2002a. Distribution and air-water exchange of carbon dioxide in the Scheldt plume off the Belgian coast. Biogeochemistry 59, $41-47$.

Borges, A.V., Frankignoulle, M., 2002b. Distribution of surface carbon dioxide and air-sea exchange in the upwelling system off the Galician coast. Global Biogeochemical Cycles 16 (2).

Borges, A.V., Frankignoulle, M., 2003. Distribution of surface carbon dioxide and air-sea exchange in the English Channel and adjacent areas. Journal of Geophysical Research 108 (C5), 3140.

Borges, A.V., Djenidi, S., Lacroix, G., Theate, J., Delille, B., Frankignoulle, M., 2003. Atmospheric $\mathrm{CO}_{2}$ flux from mangrove surrounding waters. Geophysical Research Letters 30 (11), 1558

Borges, A.V., Delille, B., Frankignoulle, M., 2005. Budgeting sinks and sources of $\mathrm{CO}_{2}$ in the coastal ocean: diversity of ecosystems counts. Geophysical Research Letters 32, L14601.

Borges, A.V., Schiettecatte, L.-S., Abril, G., Delille, B., Gazeau, F., 2006. Carbon dioxide in European coastal waters. Estuarine, Coastal and Shelf Science 70 (3) 375-387.
Borges, A.V., Tilbrook, B., Metzl, N., Lenton, A., Delille, B., 2008. Inter-annual variability of the carbon dioxide oceanic sink south of Tasmania. Biogeosciences 5, 141-155.

Bouillon, S., Boschker, H.T.S., 2006. Bacterial carbon sources in coastal sediments: a cross-system analysis based on stable isotope data of biomarkers. Biogeosciences 3, 175-185.

Bouillon, S., Frankignoulle, M., Dehairs, F., Velimirov, B., Eiler, A., Abril, G., Etcheber, H., Borges, A.V., 2003. Inorganic and organic carbon biogeochemistry in the Gautami Godavari estuary (Andhra Pradesh, India) during pre-monsoon: the local impact of extensive mangrove forest. Global Biogeochemistry Cycles 17 (4), 1114.

Bouillon, S., Dehairs, F., Velimirov, B., Abril, G., Borges, A.V., 2007a. Dynamics of organic and inorganic carbon across contiguous mangrove and seagrass systems (Gazi Bay, Kenya). Journal of Geophysical Research—Biogeosciences 112, G02018.

Bouillon, S., Dehairs, F., Schiettecatte, L.-S., Borges, A.V., 2007b. Biogeochemistry of the Tana estuary and delta (northern Kenya). Limnology and Oceanography 52 (1), 45-59.

Bouillon, S., Middelburg, J.J., Dehairs, F., Borges, A.V., Abril, G., Flindt, M.R., Ulomi, S., Kristensen, E., 2007c. Importance of intertidal sediment processes and porewater exchange on the water column biogeochemistry in a pristine mangrove creek (Ras Dege, Tanzania). Biogeosciences 4, 311-322.

Bouillon, S., Borges, A.V., Castañeda-Moya, E., Diele, K., Dittmar, T., Duke, N.C., Kristensen, E., Lee, S.Y., Marchand, C., Middelburg, J.J., Rivera-Monroy, V.H., Smith III, T.J., Twilley, R.R., 2008. Mangrove production and carbon sinks: a revision of global budget estimates. Global Biogeochemical Cycles 22 (2), GB2013, doi:10.1029/2007GB003052.

Bozec, Y., Thomas, H., Elkalay, K., de Baar, H.J.W., 2005. The continental shelf pump for $\mathrm{CO}_{2}$ in the North Sea-evidence from summer observation. Marine Chemistry 93, 131-147.

Cai, W.-J., Wang, Y., 1998. The chemistry, fluxes, and sources of carbon dioxide in the estuarine waters of the Satilla and Altamaha Rivers, Georgia. Limnology and Oceanography 43 (4), 657-668.

Cai, W.-J., Wang, Z.A., Wang, Y., 2003. The role of marsh-dominated heterotrophic continental margins in transport of $\mathrm{CO}_{2}$ between the atmosphere, the land-sea interface and the ocean. Geophysical Research Letters 30, 1849.

Cai, W.-J., Dai, M.H., Wang, Y.C., 2006. Air-sea exchange of carbon dioxide in ocean margins: a province-based synthesis. Geophysical Research Letters 33, L12603.

Carrillo, C.J., Karl, D.M., 1999. Dissolved inorganic carbon pool dynamics in northern Gerlache Strait, Antarctica. Journal of Geophysical Research 104, $15873-15884$

Chen, C.T.A., 2003. New vs. export production on the continental shelf. Deep-Sea Research II 50, 1327-1333.

Chen, C.T.A., 2004. Exchange of carbon in the coastal seas. In: Field, C.B., Raupach, M.R. (Eds.), The Global Carbon Cycle: Integrating Human, Climate and the Natural World. SCOPE, Washington, DC, pp. 341-351.

Chen, C.T.A., Tsunogai, S., 1998. Carbon and nutrients in the ocean. In: Galloway, J.N., Melillio, J.M. (Eds.), Asian Change in the Context of Global Change. Cambridge University Press, Cambridge, pp. 271-307.

Chen, C.T.A., Wang, S.L., 1999. Carbon, alkalinity and nutrient budget on the East China Sea continental shelf. Journal Geophysical Research 104, 20675-20686.

Chen, C.T.A. Liu, K.K. MacDonald, R. 2003. Continental margin exchanges. In: Fasham, M.J.R. (Ed.), Ocean Biogeochemistry: A JGOFS Synthesis. Springer, Berlin, pp. 53-97.

Chen, C.T.A., Wang, S.L., Chou, W.C., Sheu, D.D., 2006a. Carbonate chemistry and projected future changes in $\mathrm{pH}$ and $\mathrm{CaCO}_{3}$ saturation state of the South China Sea. Marine Chemistry 101, 277-305.

Chen, C.T.A., Hou, W.P., Gamo, T., Wang, S.L., 2006b. Carbonate related parameters of subsurface waters in the West Philippine, South China and Sulu Seas. Marine Chemistry 99, 151-161.

Chen, C.T.A., Holligan, P., Hong, H.S., Iseki, K., Krishnaswami, S., Wollast, R., Yoder, J., 1994. Land-ocean interactions in the coastal zone. JGOFS Report 15, SCOR, 20pp.

Chen, L.Q., Gao, Z.Y., Yang, X.L., Wang, W.Q., 2004a. Comparison of air-sea fluxes of $\mathrm{CO}_{2}$ in the Southern Ocean and the western Arctic Ocean. Acta Oceanologica Sinica 23, 647-653.

Chen, L.Q., Gao, Z.Y., Wang, W.Q., Yang, X.L., 2004b. Characteristics of $\mathrm{pCO}_{2}$ in surface water of Bering Abyssal Plain and their effects on carbon cycle in the western Arctic Ocean. Science in China Series D-Earth Sciences 47, 1035-1044.

Clark, C.D., Hiscock, W.T., Millero, F.J., Hitchcock, G., Brand, L., Miller, W.L., Ziolkowski, L., Chen, R.F., Zika, R.G., 2004. CDOM distribution and $\mathrm{CO}_{2}$ production on the Southwest Florida Shelf. Marine Chemistry 89, 145-167.

Codispoti, L.A., Friederich, G.E., Hood, D.W., 1986. Variability in the inorganic carbon system over the southeastern Bering Sea shelf during spring 1980 and spring-summer 1981. Continental Shelf Research 5, 133-160.

Copin-Montégut, C., Bégovic, M., 2002. Distributions of carbonate properties and oxygen along the water column $(0-2000 \mathrm{~m})$ in the central part of the NW Mediterranean Sea (Dyfamed site): influence of the winter vertical mixing on air-sea $\mathrm{CO}_{2}$ and $\mathrm{O}_{2}$ exchanges. Deep-Sea Research II 49, 2049-2066.

Crossland, C.J., Kremer, H.H., Lindeboom, H.J., Crossland, J.I.M., Tissier, M.D.A.Le, 2005. Coastal Fluxes in the Anthropocene. Springer, Berlin, 231pp.

de la Paz, M., Gómez-Parra, A., Forja, J., 2007. Inorganic carbon dynamic and air-water $\mathrm{CO}_{2}$ exchange in the Guadalquivir Estuary. Journal of Marine Systems 68, 265-277. 
de Madron, X.D., Civitarese G., d'Alcalà, M.R., Raimbault, P., Krasakopoulou, E., Goyet, C., 2009. The Mediterranean Sea: The shelf-slope system. In: Liu, K.K., Atkinson, L., Quiñones, R., Talaue-McManus, L. (Eds.), Carbon and Nutrient Fluxes in Continental Margins: A Global Synthesis. Springer, New York, unpublished.

DeGrandpre, M.D., Olbu, G.D., Beatty, C.M., Hammar, T.R., 2002. Air-sea $\mathrm{CO}_{2}$ fluxes on the US Middle Atlantic Bight. Deep-Sea Research II 49 (20), 4355-4367.

Ducklow, H.W., McCallister, S.L., 2004. The biogeochemistry of carbon dioxide in the coastal oceans. In: Robinsion, A.R., Brink, K. (Eds.), The Sea. Vol. 13. The Global Coastal Ocean-Multiscale Interdisciplinary Processes. Harvard University Press, Cambridge, MA, pp. 269-315 (Chapter 9).

Else, B.G.T., Papakyriakou, T.N., Yackel, J.J., Granskog, M.A., 2008. Observations of sea surface $\mathrm{fCO}_{2}$ distributions and estimated air-sea $\mathrm{CO}_{2}$ fluxes in the Hudson Bay region (Canada) during the open-water season. Journal of Geophysical Research 113, C08026, doi:10.1029/2007JC004389.

FAO, 2003. State of the World's Forests (SOFO). Food and Agriculture Organization of the United Nations, Rome, 100pp.

Fasham, M.J.R., Baliño, B.M., Bowles, C. (Editors), 2001. Contributors: Anderson, R., Archer, D., Bathmann, U., Boyd, P., Buesseler, K., Burkill, P., Bychkov, A., Carlson, C., Chen, C.T.A., Doney, S., Ducklow, H., Emerson, S., Feely, R., Feldman, G., Garcon, V., Hansell, D., Hanson, R., Harrison, P., Honjo, S., Jeandel, C., Karl, D., Le Borgne, R., Liu, K.K., Lochte, K., Louanchi, F., Lowry, R., Michaels, A., Monfray, P., Murray, J., Oschlies, A., Platt, T., Priddle, J., Quiñones, R., Ruiz-Pino, D., Saino, T., Sakshaug, E., Shimmield, G., Smith, S., Smith, W., Takahashi, T., Tréguer, P., Wallace, D., Wanninkhof, R., Watson, A., Willebrand, J., Wong C.S., 2001. A new vision of ocean biogeochemistry after a decade of the Joint Global Ocean Flux Study (JGOFS). Ambio Special Report 10, May 2001, pp. 4-31.

Ferrón, S., Ortega, T., Gómez-Parra, A., Forja, J.M., 2007. Seasonal study of dissolved $\mathrm{CH}_{4} \mathrm{CO}_{2}$ and $\mathrm{N}_{2} \mathrm{O}$ in a shallow tidal system of the bay of Cadiz (SW Spain). Journal of Marine Systems 66 (1-4), 244-257.

Frankignoulle, M., Borges, A.V., 2001. European continental shelf as a significant sink for atmospheric carbon dioxide. Global Biogeochemical Cycles 15, 569-576.

Frankignoulle, M., Gattuso, J.P., Biondo, R., Bourge, I., Copin-Montegut, G., Pichon, M., 1996. Carbon fluxes in coral reefs. II. Eulerian study of inorganic carbon dynamics and measurement of air-sea $\mathrm{CO}_{2}$ exchanges. Marine Ecology Progress Series $145(1-3), 123-132$.

Frankignoulle, M., Abril, G., Borges, A., Bourge, I., Canon, C., Delille, B., Libert, E., Théate, J.-M., 1998. Carbon dioxide emission from European estuaries. Science 282, 434-436.

Fransson, A., Chierici, M., Anderson, L.G., Bussmann, I., Kattner, G., Jones, E.P., Swift, J.H., 2001. The importance of shelf processes for the modification of chemical constituents in the waters of the Eurasian Arctic Ocean: implication for carbon fluxes. Continental Shelf Research 21 (3), 225-242.

Fransson, A., Chierici, M., Nojiri, Y., 2006. Increased net $\mathrm{CO}_{2}$ outgassing in the upwelling region of the southern Bering Sea in a period of variable marine climate between 1995 and 2001. Journal of Geophysical Research 111, C08008.

Friederich, G.E., Walz, P.M., Burczynski, M.G., Chavez, F.P., 2002. Inorganic carbon in the central California upwelling system during the 1997-1999 El Niño-La Niña event. Progress in Oceanography 54, 185-203.

Gao, X.L., Song, J.M., Li, X.Q., Yuan, H.M., Li, N., 2005. Spatial and temporal variations in $\mathrm{pH}$ and total alkalinity at the beginning of the rainy season in the Changjiang Estuary, China. Acta Oceanologica Sinica 24 (5), 68-77.

Gattuso, J.-P., Frankignoulle, M., Wollast, R., 1998. Carbon and carbonate metabolism in coastal aquatic ecosystems. Annual Review of Ecology and Systematics 29, 405-434

Gazeau, F., Smith, S.V., Gentili, B., Frankignoulle, M., Gattuso, J.-P., 2004. The European coastal zone: characterization and first assessment of ecosystem metabolism. Estuarine, Coastal and Shelf Science 60 (4), 673-694.

Gazeau, F., Borges, A.V., Barrón, C., Duarte, C.M., Iversen, N., Middelburg, J.J., Delille, B., Pizay, M.-D., Frankignoulle, M., Gattuso, J.-P., 2005. Net ecosystem metabolism in a micro-tidal estuary (Randers Fjord, Denmark): evaluation of methods and interannual variability. Marine Ecology-Progress Series 301, 23-41.

Ghosh, S., Jana, T.K., Singh, B.N., Choudhury, A., 1987. Comparative study of carbon dioxide system in virgin and reclaimed mangrove waters of Sundarbans during freshet. Mahasagar: Bulletin of the National Institute of Oceanography 20 (3), 155-161.

Goyet, C., Bradshaw, A.L., Brewer, P.G., 1991. The carbonate system in the Black Sea. Deep-Sea Research 38 (Suppl. 2), S1049-S1068.

Goyet, C., Millero, F.J., O'Sullivan, D.W., Eischeid, G., McCue, S.J., Bellerby, R.G.J., 1998. Temporal variations of $\mathrm{pCO}_{2}$ in surface seawater of the Arabian Sea in 1995. Deep-Sea Research I 45, 609-623.

Gupta, G.V.M., Sarma, V.V.S.S., Robin, R.S., Raman, A.V., Jai Kumar, M., Rakesh, M., Subramanian, B.R., 2008. Influence of net ecosystem metabolism in transferring riverine organic carbon to atmospheric $\mathrm{CO}_{2}$ in a tropical coastal lagoon (Chilka Lake, India), Biogeochemistry 87, 265-285.

Hales, B., Takahashi, T., Bandstra, L., 2005. Atmospheric $\mathrm{CO}_{2}$ uptake by a coastal upwelling system. Global Biogeochemical Cycles 19, GB1009.

Hansell, D.A., Carlson, C.A., 1998. Net community production of dissolved organic carbon. Global Biogeochemical Cycles 12, 443-453.

Hedges, J.I., Keil, R.G., Benner, R., 1997. What happens to terrestrial organic matter in the ocean? Organic Geochemistry 27 (5-6), 195-212.

Heip, C., Goosen, N.K., Herman, P.M.J., Kromkamp, J., Middelburg, J.J., Soetaert, K., 1995. Production and consumption of biological particles in temperate tidal estuaries. Oceanography and Marine Biology: An Annual Review 33, 1-149.
Hidalgo-González, R.M., Álvarez-Borrego, S., Zirino, A., 1997. Mixing in the region of the midrift islands of the Gulf of California: effect on surface $\mathrm{pCO}_{2}$. Ciencias Marinas 23, 317-327.

Hopkinson, C.S., 1988. Patterns of organic carbon exchange between coastal ecosystems: the mass balance approach in slat marsh ecosystems. In: Jansson, B.-O. (Ed.), Coastal-Offshore Ecosystem Interactions. Springer, Berlin/Heidelberg, pp. 122-154.

Hopkinson, C.S.J., Smith, E.M., 2005. Estuarine respiration: an overview of benthic pelagic and whole system respiration. In: del Giorgio, P.A., Williams, P.J.L. (Eds.), Respiration in Aquatic Ecosystems. Oxford University Press, Oxford, pp. 123-147.

Ito, R.G., Schneider, B., Thomas, H., 2005. Distribution of surface $\mathrm{fCO}_{2}$ and air-sea fluxes in the southwestern subtropical Atlantic and adjacent continental shelf. Journal of Marine Systems 56, 227-242.

Jahnke, R.A., 2009. Global synthesis. In: Liu, K.K., Atkinson, L., Quiñones R., TalaueMcManus, L. (Eds.), Carbon and Nutrient Fluxes in Continental Margins: A Global Synthesis. Springer, New York, unpublished.

Jiang, L.-Q., Cai, W.-J., Wang, Y., 2008a. Carbon dioxide degassing in river- and marine-dominated estuaries: importance of freshwater runoff. Limnology and Oceanography 53 (6), 2603-2615.

Jiang, L.-Q., Cai, W.-J., Wanninkhof, R., Wang, Y., Hüger, H., 2008b. Air-sea $\mathrm{CO}_{2}$ fluxes on the US South Atlantic Bight: spatial and seasonal variability. Journal of Geophysical Research, 113, C07019, doi:10.1029/2007JC004366.

Kang, D.-J., Kim, J.-Y., Lee, T., Kim, K.-R., 2008. Water, dissolved oxygen, phosphate and carbon, budgets of the Japan/East Sea. In: Liu, K.K., Atkinson, L., Quiñones, R., Talaue-McManus, L. (Eds.), Carbon and Nutrient Fluxes in Continental Margins: A Global Synthesis. Springer, New York, unpublished.

Kaltin, S., Anderson, L.G., 2005. Uptake of atmospheric carbon dioxide in Arctic shelf seas: evaluation of the relative importance of processes that influence $\mathrm{pCO}_{2}$ in water transported over the Bering-Chukchi Sea shelf. Marine Chemistry 94, 67-79.

Kaltin, S., Anderson, L.G., Olsson, K., Fransson, A., Chierici, M., 2002. Uptake of atmospheric carbon dioxide in the Barents Sea. Journal of Marine Systems 38 31-45.

Kawahata, H., Suzuki, A., Goto, K., 1999. Coral reefs as sources of atmospheric $\mathrm{CO}_{2}$-spatial distribution of $\mathrm{pCO}_{2}$ in Majuro Atoll. Geochemical Journal 33, 295-303.

Kayanne, H., Hata, H. Kudo, S, Yamano, H. Watanabe, A., Ikeda, Y, Nozaki, K., Kato, K., Negishi, A., Saito, H., 2005. Seasonal and bleaching-induced changes in coral reef metabolism and $\mathrm{CO}_{2}$ flux. Global Biochemical Cycles 19, GB3015.

Keil, R.G., Mayer, L.M., Quay, P.D., Richey, J.E., Hedges, J.I., 1997. Loss of organic matter from riverine particles in deltas. Geochimica et Cosmochimica acta 61 (7), 1507-1511.

Kemp, W.M., Smith, E.M., Marvin-DiPasquale, M., Boynton, W.R., 1997. Organic carbon-balance and net ecosystem metabolism in Chesapeake Bay. Marine Ecology Progress Series 150, 229-248.

Kempe, S., 1995. Coastal seas: a net source or sink of atmospheric carbon dioxide? LOICZ Report and Studies, No. 1, LOICZ International Project Office, Texel, 27pp.

Kempe, S., Pegler, K., 1991. Sinks and sources of $\mathrm{CO}_{2}$ in coastal seas: the North Sea. Tellus 43, 224-235.

Koné, Y.J.-M., Borges, A.V., 2008. Dissolved inorganic carbon dynamics in the waters surrounding forested mangroves of the Ca Mau Province (Vietnam). Estuarine, Coastal and Shelf Science 77 (3), 409-421.

Koné, Y.J.M., Abril, G., Kouadio, K.N., Delille, B., Borges, A.V., 2009. Seasonal variability of carbon dioxide in the rivers and lagoons of Ivory Coast (West Africa). Estuaries and Coasts, accepted, doi:10.1007/s12237-008-9121-0.

Körtzinger, A., 2003. A significant $\mathrm{CO}_{2}$ sink in the tropical Atlantic Ocean associated with the Amazon River plume. Geophysical Research Letters 30 (24), 2287.

Kuss, J., Roeder, W., Wlost, K.P., DeGrandpre, M.D., 2006. Time-series of surface water $\mathrm{CO}_{2}$ and oxygen measurements on a platform in the central Arkona Sea (Baltic Sea): seasonality of uptake and release. Marine Chemistry 101 220-232.

Li, X.G., Li, N., Gao, X.L., Song, J.M., 2004. Dissolved inorganic carbon and $\mathrm{CO}_{2}$ fluxes across Jiaozhou Bay air-water interface. Acta Oceanologica Sinica 23 (2), 279-285.

Li, X., Song, J., Niu, L., Yuan, H., Li, N., Gao, X., 2007. Role of the Jiaozhou Bay as a source/sink of $\mathrm{CO}_{2}$ over a seasonal cycle. Scientia Marina 71 (3), 441-450.

Liu, K.K., Atkinsion, L., Chen, C.T.A., Gao, S., Hall, J., MacDonald, R.W., TalaueMcManus, L., Quinones, R., 2000. Exploring continental margin carbon fluxes on a global scale. EOS 81, 641-642 plus 644 .

Lohrenz, S.E., Cai, W.-J., 2006. Satellite ocean color assessment of air-sea fluxes of $\mathrm{CO}_{2}$ in a river-dominated coastal margin. Geophysical Research Letter 33 L01601.

Ludwig, W., Probst, J.L., Kempe, S., 1996. Predicting the oceanic input of organic carbon by continental erosion. Global Biogeochemical Cycles 10 (1), 23-41.

Ma, L.M., Qiao, R., Zhang, B., Huang, Z.Q., Zhang, Y.H., 1999. Carbon dioxide in the East China Sea. In: Hu, D.X., Tsunogai, S. (Eds.), Margin Flux in the East China Sea. China Ocean Press, Beijing, pp. 113-123.

Mackenzie, F.T., Ver, L.M., Lerman, A., 2000. Coastal-zone biogeochemical dynamics under global warming. International Geology Review 42, 193-206.

Mackenzie, F.T., Lerman, A., Ver, L.M.B., 1998a. Role of continental margin in the global carbon balance during the past three centuries. Geology 26, 423-426.

Mackenzie, F.T., Ver, L.M.B., Lerman, A., 1998b. Coupled biogeochemical cycles of carbon, nitrogen, phosphorous and sulfur in the land-ocean-atmosphere system. In: Galloway, J.N., Melillo, J.M. (Eds.), Asian Change in the Context of Global Climate Change. Cambridge University Press, Cambridge, pp. 42-100. 
Mayer, L.M., Schick, L.L., Allison, M.A., Ruttenberg, K.C., Bentley, S.J., 2007. Marine vs. terrigenous organic matter in Louisiana coastal sediments: the uses of bromine:organic carbon ratios. Marine Chemistry 107 (2), 244-254.

Middelburg, J.J., Herman, P.M.J., 2007. Organic matter processing in tidal estuaries. Marine Chemistry 106 (1-2), 127-147.

Miller, L.A., Yager, P.L., Erickson, K.A., Amiel, D., Bâcle, J., Cochran, J.K. Garneau, M.-Ė., Gosselin, M., Hirschberg, D.J., Klein, B., LeBlanc, B., Miller, W.L., 2002. Carbon distributions and fluxes in the North Water, 1998 and 1999. Deep-Sea Research II 49, 5151-5170.

Millero, F.J., Hiscock, W.T., Huang, F., Roche, M., Zhang, J.Z., 2001. Seasonal variation of the carbonate system in Florida Bay. Bulletin of Marine Science 68 (1), $101-123$.

Moran, M.A., Sheldon, W.M., Sheldon, J.E., 1999. Biodegradation of riverine dissolved organic carbon in five estuaries of the southeastern United States. Estuaries 22 (1), 55-64.

Mukhopadhyay, S.K., Biswas, H., De, T.K., Sen, S., Jana, T.K., 2002. Seasonal effects on the air-water carbon dioxide exchange in the Hooghly Estuary, NE coast of Gulf of Bengal, India. Journal of Environmental Monitoring 4 (4), 549-552.

Muller-Karger, F.E., Varela, R., Thunell, R., Luerssen, R., Hu, C., Walsh, J.J., 2005. The importance of continental margins in the global carbon cycle. Geophysical Research Letters 32, L01602.

Murata, A., Takizawa, T., 2003. Summertime $\mathrm{CO}_{2}$ sinks in shelf and slope waters of the western Arctic Ocean. Continental Shelf Research 23, 753-776.

Nakayama, N., Watanabe, S., Tsunogai, S., 2000. Difference on $\mathrm{O}_{2}$ and $\mathrm{CO}_{2}$ gas transfer velocities in Funka Bay. Marine Chemistry 72, 115-129.

Nedashkovsky, A.P., Sapozhnikov, V.V., Sagalaev, S.G., Isaeva, A.A., Shevtsova, O.V. 1995. Variability of the carbonate system components and inorganic carbon dynamics in the western Bering Sea in summer. In: Kotenev, B.N., Sapozhnikov, V.V. (Eds.), Multiple Investigations of the Bering Sea Ecosystem. Kompleksnye issledovaniya ehkosistemy beringova moray. Moskva Russia Izd. Vniro, pp. 155-162.

Neubauer, S.C., Anderson, I.C., 2003. Transport of dissolved inorganic carbon from a tidal freshwater marsh to the York River estuary. Limnology and Oceanography 48 (1), 299-307.

Odum, H.T., Hoskin, C.M., 1958. Comparative Studies of the Metabolism of Texas Bays. Publications of the Institute of Marine Science, University of Texas 5 pp. $16-46$.

Odum, H.T., Wilson, R., 1962. Further studies on the reaeration and metabolism of Texas Bays. Publications of the Institute of Marine Science, University of Texas 8, pp. 23-55

Oh, D.C., Park, M.K., Kim, K.R., 2000. $\mathrm{CO}_{2}$ exchange at air-sea interface in the Huanghai Sea. Acta Oceanologica Sinica 19, 79-89.

Ortega, T., Ponce, R., Forja, J., Gómez-Parra, A., 2005. Fluxes of dissolved inorganic carbon in three estuarine systems of the Cantabrian Sea (north of Spain) Journal of Marine Systems 53 (1-4), 125-142.

Otsuki, A.S., Watanabe, S., Tsunogai, S., 2003. Absorption of atmospheric $\mathrm{CO}_{2}$ and its transport to the intermediate layer in the Okhotsk Sea. Journal of Oceanography 59, 709-717.

Ovalle, A.R.C., Rezende, C.E., Lacerda, L.D., Silva, C.A.R., 1990. Factors affecting the hydrochemistry of a mangrove tidal creek, Sepetiba Bay, Brazil. Estuarine Coastal and Shelf Science 31 (5), 639-650.

Peng, T.-H., Huang, J.-J., Wanninkhof, R., Millero, F.J., 1999. Carbon budget in the East China Sea in spring. Tellus 51B, 531-540.

Pérez, F.F., Ríos, A.F., Rosón, G., 1999. Sea surface carbon dioxide off the Iberian Peninsula (North Eastern Atlantic Ocean). Journal of Marine Systems 19, 27-46.

Pipko, I.I., Semiletov, I.P., Tishchenko, P.Y., Pugach, S.P., Christensen, J.P., 2002. Carbonate chemistry dynamics in Bering Strait and the Chukchi Sea. Progress in Oceanography 55, 77-94.

Rabouille, C., Mackenzie, F.T., Ver, L.M., 2001. Influence of the human perturbation on carbon, nitrogen, and oxygen biogeochemical cycles in the global coasta ocean. Geochimica et Cosmochimica Acta 65, 3615-3641.

Ralison, O.H., Borges, A.V., Dehairs, F., Middelburg, J.J., Bouillon, S., 2008. Carbon biogeochemistry of the Betsiboka Estuary (north-western Madagascar). Organic Geochemistry 39(12), 1649-1658, doi:10.1016/j.orggeochem.2008. 01.010

Raymond, P.A., Bauer, J.E., 2000. Bacterial consumption of DOC during transport through a temperate estuary. Aquatic Microbial Ecology 22 (1), 1-12.

Raymond, P.A., Bauer, J.E., Cole, J.J., 2000. Atmospheric $\mathrm{CO}_{2}$ evasion, dissolved inorganic carbon production, and net heterotrophy in the York River estuary. Limnology and Oceanography 45 (8), 1707-1717.

Rehder, G., Suess, E., 2001. Methane and $\mathrm{pCO}_{2}$ in the Kuroshio and the South China Sea during maximum summer surface temperatures. Marine Chemistry 75 (1-2), 89-108.

Richey, J.E., 2004. Pathways of atmospheric $\mathrm{CO}_{2}$ through fluvial systems. In: Field C.B., Raupach, M.R. (Eds.), The Global Carbon Cycle, Integrating Humans, Climate, and the Natural World. Island Press, Washington, Covelo, London, pp. 329-340.

Sabine, C.L., Mackenzie, F.T., 1991a. Oceanic sinks for anthropogenic $\mathrm{CO}_{2}$. Journal Energy, Environment and Economics 1,119-127.

Sabine, C. L., Mackenzie, F.T., 1991b. Oceanic sinks for anthropogenic $\mathrm{CO}_{2}$. In: Energy and Environmental Progress Series F, Environment and Energy. Nova Science, pp. 367-382.

Sarma, V.V.S.S., Kumar, M.D., Manerikar, M., 2001. Emission of carbon dioxide from a tropical estuarine system, Goa, India. Geophysical Research Letters 28 (7), 1239-1242.
Santana-Casiano, J.M., Gonzalez-Davila, M., Laglera, L.M., 2002. The carbon dioxide system in the Strait of Gibraltar. Deep-Sea Research II 49, 4145-4161.

Santana-Casiano, J.M., González-Dávila, M., 2009. Carbon dioxide fluxes in the Benguela upwelling system during winter and spring. A comparison between 2005 and 2006. Deep-Sea Research II, this issue [doi:10.1016/j.dsr2.2008. $12.010]$.

Schiettecatte, L.-S., Thomas, H., Bozec, Y., Borges, A.V., 2007. High temporal coverage of carbon dioxide measurements in the Southern Bight of the North Sea. Marine Chemistry 106 (1-2), 161-173.

Shim, J.H., Kim, D.S., Kang, Y.C., Lee, J.H., Jang, S.T., Kim, C.H., 2007. Seasonal variations in $\mathrm{pCO}_{2}$ and its controlling factors in surface seawater of the northern East China Sea. Continental Shelf Research 27 (20), 2623-2636.

Smith, S.V., 1973. Carbon dioxide dynamics: a record of organic carbon production, respiration, and calcification in the Eniwetok reef flat community. Limnology and Oceanography 18, 106-120.

Smith, S.V., Mackenzie, F.T., 1987. The ocean as a net heterotrophic system: implications from the carbon biogeochemical cycle. Global Biogeochemical Cycles 1, 187-198.

Smith, S.V., Hollibaugh, J.T., 1993. Coastal metabolism and the oceanic carbon balance. Reviews of Geophysics 31, 75-89.

Stoll, M.H.C., Thomas, H., De Baar, H.J.W., Zondervan, I., De Jong, E., Bathmann, U.V., Fahrbach, E., 2002. Biological versus physical processes as drivers of large oscillations of the air-sea $\mathrm{CO}_{2}$ flux in the Antarctic marginal ice zone during summer. Deep-Sea Research I 49, 1651-1667.

Takahashi, T., Sutherland, S.C., Sweeney, C., Poisson, A., Metzl, N., Tilbrook, B., Bates, N., Wanninkhof, R., Feely, R.A., Sabine, C., Olafsson, J., Nojiri, Y., 2002. Global sea-air $\mathrm{CO}_{2}$ flux based on climatological surface ocean $\mathrm{pCO}_{2}$, and seasonal biological and temperature effects. Deep-Sea Research II 49 (9-10), 1601-1622.

Takahashi, T., Sutherland, S.C., Feely, R.A., Wanninkhof, R., 2006. Decadal change of the surface water $\mathrm{pCO}_{2}$ in the North Pacific: a synthesis of 35 years of observations. Journal of Geophysical Research 111 (C7), C07S05.

Takahashi, T., Sutherland, S.C., Wanninkhof, R., Sweeney, C., Feely, R.A., Chipman, D., Hales, B., Friederich, G., Chavez, F., Watson, A., Bakker, D., Schuster, U., Metzl, N., Inoue, H.Y., Ishii, M., Midorikawa, T., Sabine, C., Hoppema, M., Olafsson, J., Amarson, T., Tilbrook, B., Johannessen, T., Olsen, A., Bellerby, R., De Baar, H., Nojiri, Y., Wong, C.S., Delille B., Bates, N., 2009. Climatological mean and decadal change in surface ocean $\mathrm{pCO}_{2}$, and net sea-air $\mathrm{CO}_{2}$ flux over the global oceans, Deep-Sea Research II, this issue [doi:10.1016/j.dsr2.2008.12.009].

Ternon, J.F., Oudot, C., Dessier, A., Diverres, D., 2000. A seasonal tropical sink for atmospheric $\mathrm{CO}_{2}$ in the Atlantic Ocean: the role of the Amazon River discharge. Marine Chemistry 68, 183-201.

Thomas, H., Bozec, Y., de Baar, H., Elkalay, K., Frankignoulle, M., Kuhn, W., Lenhart, H., Moll, A., Patscgm J., Radach, G., Schiettecatte, L.-S., Borges, A.V., 2008. Carbon and nutrient budgets of the North Sea. In: Liu, K.K., Atkinson, L., Quiñones R., Talaue-McManus, L. (Eds.), Carbon and Nutrient Fluxes in Continental Margins: A Global Synthesis. Springer, New York, unpublished.

Thomas, H., Bozec, Y., Elkalay, K., de Baar, H.J.W., 2004. Enhanced open ocean storage of $\mathrm{CO}_{2}$ from shelf sea pumping. Science 304, 1005.

Thomas, H., Bozec, Y., de Baar, H.J.W., Elkalay, K., Frankignoulle, M., Schiettecatte, L.-S., Kattner, G., Borges, A.V., 2005. The Carbon budget of the North Sea. Biogeosciences 2, 87-96.

Thomas, H., Prowe, F., van Heuven, S., Bozec, Y., de Baar, H.J.W., Schiettecatte, L.-S., Suykens, K., Koné, M., Borges, A.V., Lima, I.D., Doney, S.C., 2007. Rapid decline of the $\mathrm{CO}_{2}$ buffering capacity in the North Sea and implications for the North Atlantic Ocean. Global Biogeochemical Cycles 21, GB4001.

Tsunogai, S., Watanabe, S., Nakamura, J., Ono, T., Sato, T., 1997. A preliminary study of carbon system in the East China Sea. Journal of Oceanography 53, 9-17.

Tsunogai, S., Watanabe, S., Sato, T., 1999. Is there a "continental shelf pump" for the absorption of atmospheric $\mathrm{CO}_{2}$. Tellus Series B 51, 701-712.

Ver, L.M.B., Mackenzie, F.T., Lerman, A., 1999a. Carbon cycle in the coastal zone: effects of global perturbations and change in the past three centuries. Chemical Geology 159, 283-304.

Ver, L.M.B., Mackenzie, F.T., Lerman, A., 1999b. Biogeochemical responses of the carbon cycle to natural and human perturbations: past, present, and future. American Journal of Science 299, 762-801.

Walsh, J.J., 1988. On the Nature of Continental Shelves. Academic Press, New York.

Walsh, J.J., 1991. Importance of continental margins in the marine biogeochemical cycling of carbon and nitrogen. Nature 350, 53-55.

Walsh, J.J., Dieterle, D.A., 1994. $\mathrm{CO}_{2}$ cycling in the coastal ocean. I-A numerical analysis of the southeastern Bering Sea with applications to the Chuckchi Sea and the northern Gulf of Mexico. Progress in Oceanography 34, 335-392.

Wakita, M., Watanabe, Y.W., Watanabe, S., Noriki, S., Wakatsuchi, M., 2003. Oceanic uptake rate of anthropogenic $\mathrm{CO}_{2}$ in a subpolar marginal sea: the Sea of Okhotsk. Geophysical Research Letters 30 (24), 2252.

Wang, S.L., Chen, C.T.A., Hong, G.H., Chung, C.S., 2000. Carbon dioxide and related parameters in the East China Sea. Continental Shelf Research 20, 525-544.

Wang, B.D., Liu, F., Zhan, R., 2001. A review of the biogeochemical study on biogenic elements in the Yellow Sea. Journal of Oceanography of Huanghai and Boahi Seas 19, 99-106.

Wang, W.Q., Huang, X.B., Zhang, Y.H., 1998. Differences of $\mathrm{CO}_{2}$ partial pressure between sea-air and its flux in South Indian Ocean. Journal of Oceanography in Taiwan Strait 17, 262-268 (in Chinese with English abstract).

Wang, W.Q., Yang, X.T., Huang, H.B., Chen, L.Q., 2003. Investigation on distribution and fluxes of sea-air $\mathrm{CO}_{2}$ of the expedition areas in the Arctic Ocean. Science in China Series D-Earth Sciences 46, 569-580. 
Wang, Z.A., Cai, W.-J., 2004. Carbon dioxide degassing and inorganic carbon export from a marsh-dominated estuary (the Duplin River): a marsh $\mathrm{CO}_{2}$ pump. Limnology and Oceanography 49 (2), 341-354.

Wanninkhof, R., Hitchcock, G., Wiseman, W.J., Vargo, G., Ortner, P.B., Asher, W., Ho, D.T., Schlosser, P., Dickson, M.-L., Masserini, R., Fanning, K., Zhang, J.-Z., 1997. Gas exchange, dispersion, and biological productivity on the west Florida shelf: results from a Lagrangian tracer study. Geophysical Research Letters 24 (14), 1767-1770.

Wiegner, T.N., Seitzinger, S.P., 2001. Photochemical and microbial degradation of external dissolved organic matter inputs to rivers. Aquatic Microbial Ecology 24, 27-40.

Wollast, R., 1998. Evaluation and comparison of the global carbon cycle in the coastal zone and in the open ocean. In: Brink, K.H., Robinson, A.R. (Eds.), The Global Coastal Ocean. Wiley, New York, pp. 213-252.

Woodwell, G.M., Rich, P.H., Hall, C.A.S., 1973. Carbon in estuaries. In: Woodwell, G.M., Pecan, E.V. (Eds.), Carbon and the Biosphere. Springfield, Virginia, pp. 221-240.
Yager, P.L., Wallace, D.W.R., Johnson, K.M., Smith Jr., W.O., Minnett, P.J., Deming J.W., 1995. The Northeast Polynya as an atmospheric $\mathrm{CO}_{2}$ sink: a seasona rectification hypothesis. Journal of Geophysical Research 100, 4389-4398.

Yool, A., Fasham, M.J.R., 2001. An examination of the "continental shelf pump" in an open ocean general circulation model. Global Biogeochemical Cycles 15, 831-844.

Zhai, W., Dai, M., Cai, W.-J., Wang, Y., Wang, Z., 2005. High partial pressure of $\mathrm{CO}_{2}$ and its maintaining mechanism in a subtropical estuary: the Pearl River estuary, China. Marine Chemistry 93, 21-32.

Zhai, W., Dai, M., Guo, X., 2007. Carbonate system and $\mathrm{CO}_{2}$ degassing fluxes in the inner estuary of Changjiang (Yangtze) River, China. Marine Chemistry 107 (3), 342-356.

Zhang, H., 1999. The surface flux of carbon dioxide in the shelf region of the East China Sea. In: Hu, D.X., Tsunogai, S. (Eds.), Margin Flux in the East China Sea. China Ocean Press, Beijing, pp. 124-131.

Zhang, L.J., Wang, B.Y., Zhang, J., 1999. pCO $_{2}$ in the surface water of the East China Sea in winter and summer. Journal of Ocean University of Qingdao 29, 149-153. 